\title{
Ecological and evolutionary response of Tethyan planktonic foraminifera to the middle Eocene climatic optimum (MECO) from the Alano section (NE Italy)
}

\author{
Valeria Luciani $^{\text {a,* }}$, Luca Giusberti ${ }^{\text {b }}$, Claudia Agnini ${ }^{\text {b,c }}$, Eliana Fornaciari ${ }^{\text {b }}$, Domenico Rio ${ }^{\text {, }}$, \\ David J.A. Spofforth ${ }^{\mathrm{d}}$, Heiko Pälike ${ }^{\mathrm{d}}$ \\ a Dipartimento di Scienze della Terra - Polo Scientifico Tecnologico, Università di Ferrara, Via G. Saragat, 1, I-44100, Ferrara, Italy \\ b Dipartimento di Geoscienze, Università di Padova, Via Giotto, 1, I-35137 Padova, Italy \\ c Istituto di Geoscienze e Georisorse, CNR-Padova c/o Dipartimento di Geoscienze, Università di Padova, Via Giotto, 1, I-35137 Padova, Italy \\ ${ }^{\mathrm{d}}$ National Oceanography Centre, Southampton, University of Southampton Waterfront Campus, European Way, SO14 3ZH Southampton, United Kingdom
}

\section{A R T I C L E I N F O}

\section{Article history:}

Received 17 September 2009

Received in revised form 5 March 2010

Accepted 8 March 2010

Available online $\mathrm{xxxx}$

\section{Keywords:}

Middle Eocene climatic optimum

Planktonic foraminifera

Paleoecology

Evolution

Southern Alps

Italy

\begin{abstract}
A B S T R A C T
The enigmatic middle Eocene climatic optimum (MECO) is a transient $(\sim 500 \mathrm{kyr})$ warming event that significantly interrupted at $\sim 40 \mathrm{Ma}$ the long-term cooling through the middle and late Eocene, eventually resulting in establishment of permanent Antarctic ice-sheet. This event is still poorly known and data on the biotic response are so far scarce. Here we present a detailed planktonic foraminiferal analysis of the MECO interval from a marginal basin of the central-western Tethys (Alano section, northeastern Italy). The expanded and continuous Alano section provides an excellent record of this event and offers an appealing opportunity to better understand the role of climate upon calcareous plankton evolution. A sapropel-like interval, characterized by excursions in both the carbon and oxygen bulk-carbonate isotope records, represents the lithological expression of the post-MECO event in the study area and follows the $\delta^{18} \mathrm{O}$ negative shift, interpreted as representing the MECO warming.

High-resolution quantitative analysis performed on both $>38 \mu \mathrm{m}$ and $>63 \mu \mathrm{m}$ fractions reveals pronounced and complex changes in planktonic foraminiferal assemblages indicating a strong environmental perturbation that parallels the variations of the stable isotope curves corresponding to the MECO and post-MECO intervals. These changes consist primarily in a marked increase in abundance of the relatively eutrophic subbotinids and of the small, low-oxygen tolerant Streptochilus, Chiloguembelina and Pseudohastigerina. At the same time, the arrival of the abundant opportunist eutrophic Jenkinsina and Pseudoglobigerinella bolivariana, typical species of very high-productivity areas, also occurs. The pronounced shift from oligotrophic to more eutrophic, opportunist, low-oxygen tolerant planktonic foraminiferal assemblages suggests increased nutrient input and surface ocean productivity in response to the environmental perturbation associated with the MECO. Particularly critical environmental conditions have been reached during the deposition of the sapropel-like beds as testified by the presence of common giant and/or odd morphotypes. This is interpreted as evidence of transient alteration in the ocean chemistry.

The enhanced surface water productivity inferred by planktonic foraminiferal assemblages at the onset of the event should have resulted in heavier $\delta^{13} \mathrm{C}$ values. The recorded lightening of the carbon stable isotope preceding the maximum warmth therefore represents a robust indication that it derives principally by a conspicuous increase of $\mathrm{pCO}_{2}$. The increased productivity of surface waters, also supported by geochemical data, may have acted as mechanism for $p \mathrm{CO}_{2}$ reduction and returned the climate system to the general Eocene cooling trend. The oxygen-depleted deep waters and the organic carbon burial following the peak of the MECO event represent the local response to the MECO warming and suggest that high sequestration of organic matter, if representing a widespread response to this event, might have contributed to the decrease of $p \mathrm{CO}_{2}$ as well. Though the true mechanisms are still obscure, several lines of evidence indicate a potential pressure on planktonic foraminiferal evolution during the $\mathrm{MECO}$ event including permanent changes besides transient and ecologically controlled variations.
\end{abstract}

(c) 2010 Elsevier B.V. All rights reserved.

\footnotetext{
* Corresponding author.

E-mail address: lcv@unife.it (V. Luciani).
}

\section{Introduction}

The early Paleogene is increasingly attracting the attention of the scientific community as it represents one of the more climatically and evolutionary dynamic periods in the Earth history. The available 
paleoclimatic records (e.g. Zachos et al., 2001, 2008) indicate that the Earth climate system reached a peak of global warming during the early Eocene climatic optimum (EECO, 50-52 Ma) within an extended interval of greenhouse-climate regime. Several short-lived extreme warming events, referred to as hypertermals, are superimposed to this general trend in the late Paleocene to early Eocene interval (e. g., Kennett and Stott, 1991; Lourens et al., 2005; Nicolò et al., 2007; Zachos et al., 2008; Stap et al., 2009). The maximum warming was followed by a long-term cooling trend through the middle-late Eocene ( $\sim 9$ to $34 \mathrm{Ma}$ ) eventually leading to a major threshold at the base of the Oligocene (Miller et al., 1991), when the modern icehouse world became definitively established. This fundamental transition of the Earth climatic system, the so-called doubthouse world (Miller et al., 1991), is however still poorly known. Superimposed on the long-term cooling trend there are episodes of climatic instability testified by a series of transient warming (Bohaty and Zachos, 2003; Sexton et al., 2006; Edgar et al., 2007a), cooling and/or glaciation events (Tripati et al., 2005; Edgar et al., 2007a). In particular, the middle Eocene climatic evolution seems to be characterized by at least one prominent transient ( $\sim 500 \mathrm{kyr}$ ) warming event at the top of Chron C18r at $\sim 40 \mathrm{Ma}$, known as the middle Eocene climatic optimum (MECO) (Bohaty and Zachos, 2003; Sexton et al., 2006; Bohaty et al., 2009). This event significantly interrupted the overall cooling trend of the middle Eocene. Originally documented in several deep-sea sites of the Southern Ocean (Bohaty and Zachos, 2003; Villa et al., 2008), the MECO now appears to be recorded worldwide by pronounced changes in $\delta^{13} \mathrm{C}$ and $\delta^{18} \mathrm{O}$ values and coeval oscillations in global carbonate compensation depth (CCD, Tripati et al., 2005; Bohaty et al., 2009). Even more interest is dedicated to this enigmatic warming event in order to assess its timing, characters and nature (e. g. Bohaty et al., 2009; Spofforth et al., in press).

Previous isotopic and bio-magnetostratigraphic studies (Agnini et al., in press; Spofforth et al., in press) have defined the occurrence of the MECO event within the Alano di Piave section (hereafter referred to as Alano), northeastern Italy (Figs. 1 and 2). Associated with and

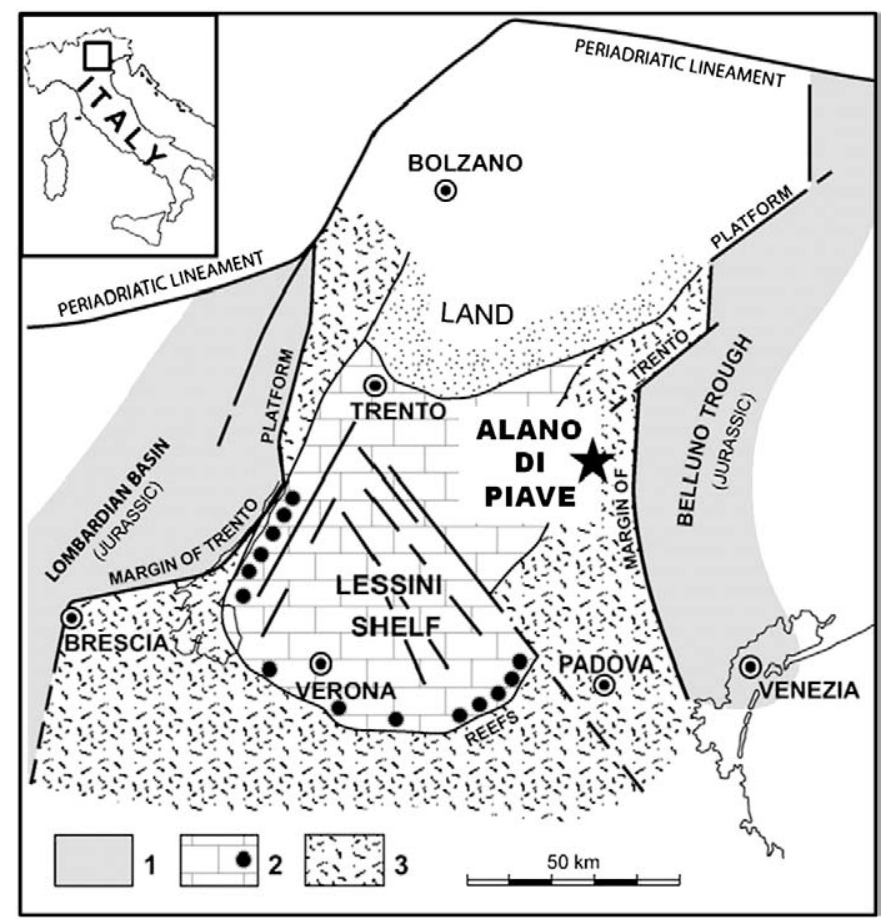

Fig. 1. Main paleogeographic elements of the Southern Alps during the Paleogene (modified from Bosellini, 1989 and Bosellini and Papazzoni, 2003) and location of the Alano di Piave (referred to as Alano section in the text) section (star). Legend: 1) deepwater mudstones of the Jurassic basins; 2) Paleogene lagoon and shelf edge reefs; 3 ) Palaeogene pelagic claystones and marlstones. following the peak of MECO two organic-rich sapropel-like intervals were deposited. The isotope shifts in both $\delta^{13} \mathrm{C}$ and $\delta^{18} \mathrm{O}$ values recorded at Alano are comparable in magnitude and stratigraphic position to the MECO observed in Southern Ocean and central Tethys (Bohaty and Zachos, 2003; Jovane et al., 2007; Bohaty et al., 2009).

The expanded and continuous Alano section provides an excellent record of the MECO that occurred in a marginal basin of the centralwestern Tethys. This study forms part of a multi-proxy approach to fully understand the biotic and environmental responses to the MECO event. Specifically, in this paper we aim to: 1 ) investigate the possible cause-effect relationship between changes in foraminiferal assemblages and modifications of environmental conditions; 2) distinguish the biotic changes bounded to the warming event, and thus ephemeral, from long-lasting and permanent evolutionary events. The Alano section provides therefore an exceptional opportunity to better comprehend the role, if any, played by the MECO-related changes upon calcareous plankton evolution.

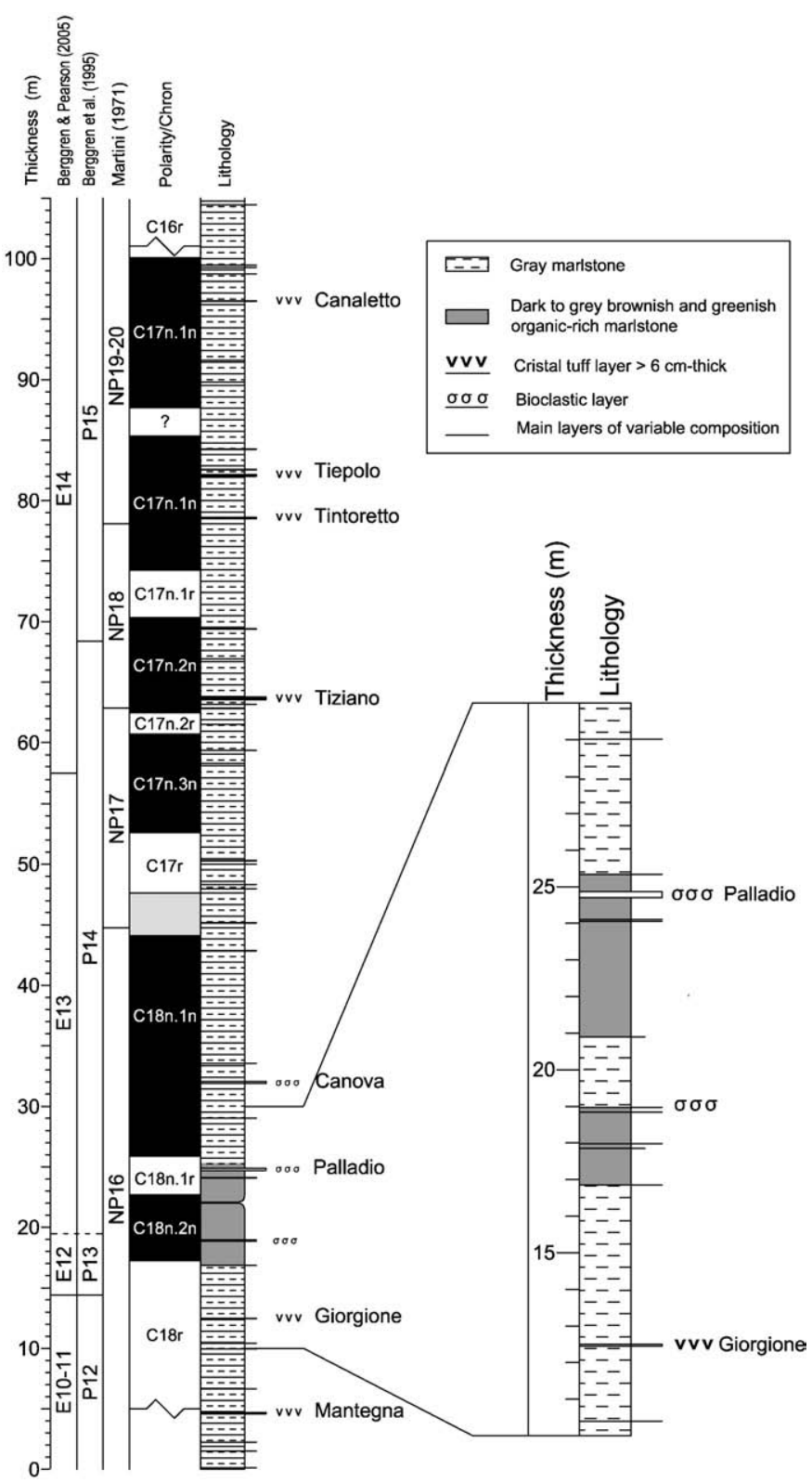

Fig. 2. Simplified columnar log of the Eocene Alano section. Bio-magnetostratigraphy is from Agnini et al., in press. The blow-up shows the segment straddling the MECO interval object of this study. 


\section{Setting, lithology and biochronostratigraphy}

The Alano section outcrops in the Venetian Southern Alps (Fig. 1) and is the potential candidate for defining the GSSP of the Middle Eocene/Late Eocene boundary (Agnini et al., in press). This section was deposited in the Belluno Basin, a paleogeographic unit formed in the Jurassic from regional rifting, breaking up and subsequent collapse of the Triassic shallow-water carbonate platforms (e. g., Winterer and Bosellini, 1981). Deep-water facies persisted in the south-western sector of the Belluno Basin, surrounded by shallower areas to the west (Lessini Shelf of Bosellini, 1989) and east (Friuli Platform; Fig. 1), until the late Eocene (Cita, 1975; Trevisani, 1997). The Alano section is located within this area of the Belluno Basin and is interpreted as deposited in a middle-bathyal setting (Agnini et al., in press).

Lithologically, the entire Alano section consists of $120-130 \mathrm{~m}$ of bathyal gray marls (Fig. 2). The bio-magnetostratigraphic data collected throughout the section provide a sound chronostratigraphic frame indicating that the section extends from the upper part of the Chron C18r ( 41.5 Ma) to the base of Chron C16r ( 36.5 Ma). The interval of the Alano section here investigated spans the planktonic foraminiferal zones E10-11, E12 and lower E13 (Berggren and Pearson, 2005) or P12 to lower P14 (Berggren et al., 1995) and the calcareous nannofossil zone NP16 (Martini, 1971) or CP 14a (Okada and Bukry, 1980). The age-model adopted here follows Agnini et al. (in press).

In the lower part (from $\sim 17$ to $\sim 25 \mathrm{~m}$ above the base of the section) the monotonous marl sedimentation is interrupted by $\sim 8 \mathrm{~m}$ thick sapropel-like interval, consisting of laminated dark to black marlstones, that are the main focus of this paper. The sapropel-like interval is further split into 2 units by a lighter coloured, organic-poor interval from $\sim 19$ to $\sim 21 \mathrm{~m}$. These two organic-rich units (ORG1 and ORG2) are associated with increases in the concentration of sulphur and redox-sensitive trace metals, very low concentrations of $\mathrm{Mn}$ and the occurrence of pyrite (Spofforth et al., in press).

Major and distinct shifts in both bulk stable $\delta^{13} \mathrm{C}$ and $\delta^{18} \mathrm{O}$ records are present within this interval and correlate with the MECO event
(Fig. 3). Specifically, the interval representing the MECO is here identified in agreement with Bohaty et al. (2009) as strictly corresponding to the negative shift of the oxygen-isotope (from $\sim 13 \mathrm{~m}$ to $\sim 17 \mathrm{~m}$ ). The initiation of the MECO occurs in our section within the upper part of magnetochron $\mathrm{C} 18 \mathrm{r}$ at $\sim 40.5 \mathrm{Ma}$ with minimum $\delta^{18} \mathrm{O}$ and $\delta^{13} \mathrm{C}$ values observed at the base of $\mathrm{C} 18 \mathrm{n} .2 \mathrm{n}$ $\sim 40.13 \mathrm{Ma}$, which are interpreted to represent possible peak warming conditions (Spofforth et al., in press).

The overlying interval, that includes the ORG1 and ORG2 horizons and the articulated shifts of $\delta^{13} \mathrm{C}$ bulk record, is here defined as the post-MECO interval (from $\sim 17 \mathrm{~m}$ to $\sim 25 \mathrm{~m}$; Fig. 3). According to our age-model, the duration of the entire MECO and post-MECO interval can be estimated in 800-900 kyr (Spofforth et al., in press). At Alano, the main recovery of the $\delta^{18} \mathrm{O}$ curve to values preceding the major shift is on timescales of less than $100 \mathrm{kyr}$, an estimation similar to that from the Southern Ocean, interpreted as representing a relatively rapid cooling following the $\sim 500 \mathrm{kyr}$ MECO warming (Bohaty and Zachos, 2003; Bohaty et al., 2009).

\section{Materials and methods}

\subsection{Planktonic foraminifera and radiolarians}

Forty-five samples from a $22 \mathrm{~m}$ interval straddling the MECO were prepared for the planktonic foraminiferal study. Standard methods, consisting of disaggregation of the indurate marlstones with hydrogen peroxide at concentrations varying from 10\% to 30\%, were used. Where needed, samples were additionally treated using a surfacetension-active chemical product. Finally, to break up clumps of residue, some samples were placed in a gentle ultrasonic bath. All samples were washed through a $38 \mu \mathrm{m}$-mesh sieve in order to avoid the loss of the very small specimens that are significant for the paleoecological interpretation. The finest fraction was separated from the $>63 \mu \mathrm{m}$ residue.

The sample spacing is on average $40 \mathrm{~cm}$ over the interval corresponding to the major stable isotope shifts. We adopted a wider

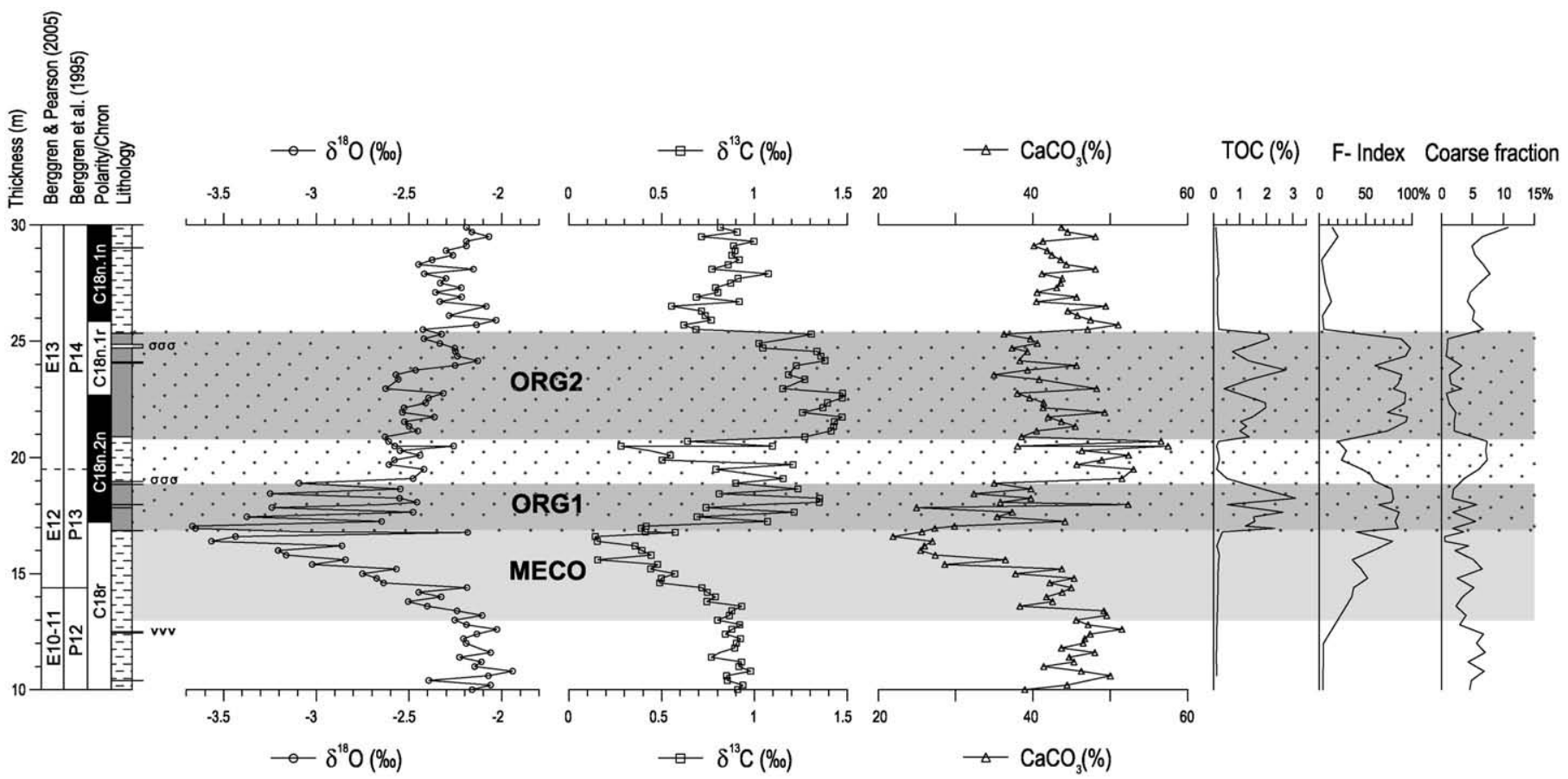

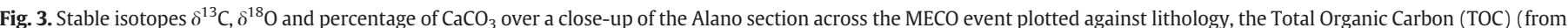

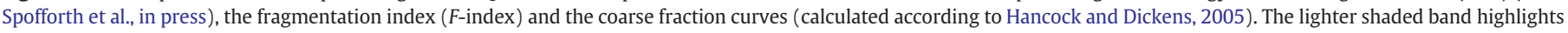

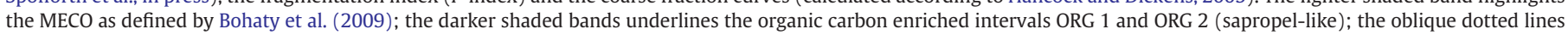
individuate the post-MECO interval. 
sampling spacing from $60 \mathrm{~cm}$ to $2 \mathrm{~m}$ below and above the critical interval. Quantitative analyses were carried out both in the $>63 \mu \mathrm{m}$ and $>38 \mu \mathrm{m}$ fractions by counting the relative abundance of genera or group of genera (considering the entire or almost entire specimens), expressed in percentage, on a population of about 300 specimens. The preservation varies from good, in the lower and upper part of the sections studied, to moderate or poor, within ORG1 and ORG2 where pyritization frequently occurred, mainly testified by the presence of internal moulds. Taxonomic criteria adopted in this study are after Pearson et al. (2006). The subbotinids includes, beside Subbotina, the ecologically similar genera Parasubbotina that, however, constitute a minor component of this group. The other groups of genera were compiled according to their known ecological affinities. The most representative taxa were illustrated on Plate 1 by scanning electron microscope (SEM) photos.

Radiolarian abundances were estimated in the same set of samples as relative percentage with respect to planktonic foraminifera by counting number of specimens on 300 tests in the $>63 \mu \mathrm{m}$ fraction.

\subsection{Foraminiferal fragmentation}

We evaluated the degree of dissolution by counting the number of planktonic foraminiferal fragments or partially dissolved tests vs entire tests on 300 elements (expressed in percentages) according to Hancock and Dickens (2005). Fragmented foraminifera include specimens showing notable deterioration, missing chambers and substantial breakage. Dissolution is expressed as fragmentation index (F-index).

\subsection{Weight percent coarse fraction}

The entire $>38 \mu \mathrm{m}$ residue (included the $>63 \mu \mathrm{m}$ fraction) obtained for 59 sample was dried and weighed. The weight percent ratio of the $>38 \mu \mathrm{m}$ size fraction to the weight of the bulk sample (usually about $100 \mathrm{~g}$ for each sample) is here referred as coarse fraction according to Hancock and Dickens (2005). The coarse fraction is a possible indicator of dissolution: carbonate dissolution commonly leads to fragmentation of foraminiferal tests, which decreases the coarse size fraction of bulk sediment (e.g. Berger et al., 1982; Broecker and Clark, 1999).

\subsection{Stable isotopes, $\mathrm{CaCO}_{3}$ and total organic carbon}

Over 100 samples were analyzed from this interval for $\mathrm{CaCO}_{3}$, total organic carbon (TOC) and bulk $\delta^{18} \mathrm{O}$ and $\delta^{13} \mathrm{C}$ isotopes using standard methods (Spofforth et al., in press). Although some pyritization and dissolution has occurred within ORG1 and ORG2, the data are considered to give a reliable signal through this interval and have been correlated to other global records using the $\delta^{13} \mathrm{C}$ isotope stratigraphy. For details on adopted techniques and a full discussion of the geochemical data see Spofforth et al. (in press).

\section{Results}

\subsection{Bulk $\delta^{13} \mathrm{C}$ and $\delta^{18} \mathrm{O}$ isotope data and $\mathrm{CaCO}_{3}$ record}

Bulk carbon and oxygen isotopes, and $\mathrm{CaCO}_{3}$ and $\mathrm{TOC}$ are shown in Fig. 3 (Spofforth et al., in press). A prominent transient isotope excursion begins at $\sim 13 \mathrm{~m}$. Bulk $\delta^{18} \mathrm{O}$ records a negative shift of up to $\sim 1.8 \%$ o with the minimum $\delta^{18} \mathrm{O}$ values at $\sim 17 \mathrm{~m}$, coincident with the beginning of ORG1 (Spofforth et al., in press). Similarly $\delta^{13} \mathrm{C}$ and $\mathrm{CaCO}_{3}$ record minimum values of $0.2 \%$ (from $1 \%$ ) and $20 \%$ (from $50 \%)$ respectively. Although the $\delta^{18} \mathrm{O}$ record gradually recovers to near-pre-event values by $25 \mathrm{~m}$, the $\delta^{13} \mathrm{C}$ and $\mathrm{CaCO}_{3}$ records are more complex and are strongly correlated to the observed lithological changes. Two rapid positive $\delta^{13} \mathrm{C}$ excursions are interrupted by a negative excursion to near peak event values at $\sim 19$ and $\sim 21 \mathrm{~m}$. The two positive carbon-isotope excursions are similar in magnitude (1.25\%) and are coincident with elevated TOC content (up to 3\%). At the beginning of the ORG1 the $\mathrm{CaCO}_{3}$ recovers to maximum values occurring in the 19-21 m interval with a small decrease $(\sim 5 \%)$ in the second organic-rich layer (ORG2).

\subsection{Planktonic foraminifera}

Planktonic foraminiferal assemblages show prominent changes in composition and relative abundances across the $\sim 20 \mathrm{~m}$ thick interval investigated. They appear well preserved and diversified from the intervals preceding and following the isotope shifts with most of the typical middle Eocene genera and species of subtropical-temperate latitudes represented (Fig. 4). As recorded in other NE Italian sections (Toumarkine and Luterbacher, 1985; Luciani and Lucchi Garavello, 1986), the middle-late Eocene genus Hantkenina displays an uneven distribution and, where present, constitutes a minor component of the assemblages.

Pronounced changes in both the relative abundance and assemblages composition distinctly occur across the MECO interval, starting at the onset of the isotope shifts. These changes in planktonic foraminiferal assemblages are displayed in Figs. 4-6.

One of the most significant changes consists in a distinct reduction in the abundance of the symbiont-bearing, warm-indices large acarininids that virtually collapses from $\sim 40 \%$ to about less than $10 \%$ of the total population at $\sim 40 \mathrm{Ma}$ (Fig. 4 ). Tough the genus Morozovelloides shows the same behaviour as Acarinina, its decline is less evident since it is scarcely abundant throughout the Alano section. Neither the large acarininids or the Morozovelloides recover to preisotope excursion values after the MECO event, until they definitely disappear at $\sim 38 \mathrm{Ma}$, near the Bartonian/Priabonian boundary (Fig. 6).

The deep-dweller subbotinids also show significant changes across this interval (Fig. 4). Their abundance peaks at $80 / 90 \%$ of the assemblages within the sapropel-like intervals, where some changes in composition are also recorded. Specifically, the subbotinids abundance in ORG1 and ORG2 includes an increase of the deepwater dwelling Parasubbotina griffinae. This species is very rare and

\footnotetext{
Plate 1.

1-28. Selected planktonic foraminifera from the stratigraphic interval corresponding to the MECO event at the Tethyan Alano section (northeastern Italy).

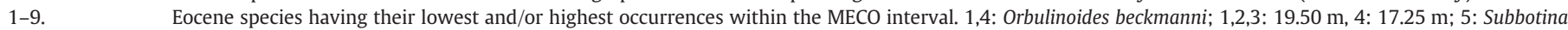
gortanii, 15,20 m (LO of the species); 6-9: Turborotalia cocoaensis, 6,7, $15.60 \mathrm{~m}$ (LO of the species); 8,9, $16.80 \mathrm{~m}$.

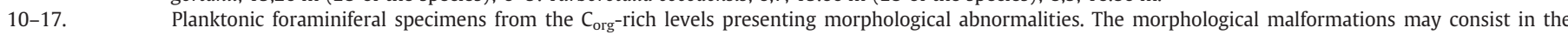
anomalous elongation of the last chamber (subbotinids of figures $11-14.40 \mathrm{~m}, 12-17.25 \mathrm{~m}, 13-18.65 \mathrm{~m}, 14-14.40 \mathrm{~m}, 15-14.40 \mathrm{~m}$ ), in abnormal chamberlike protrusions (specimen 10, $23.55 \mathrm{~m}$ ), in aberrant coiling $(16,17.25 \mathrm{~m}, 17,17.65)$. The specimens of the figures 13 and 16 display exceptional large-sized tests.

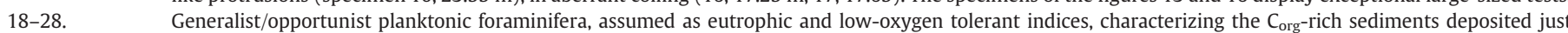
above the main oxygen and carbon-isotope excursion at the Alano section. 18-19: Pseudoglobigerinella bolivariana, 18, $17.25 \mathrm{~m}, 19,17.65 \mathrm{~m}$; 20: Pseudohastigerina micra, 17.98 m; 21-22: Streptochilus martini 17.98 m; 23: Chiloguembelina cubensis; 24: C. ototara, 17.98 m; 25: Zeauvigerina zelandica 17.98 m; 26-28: Jenkinsina columbiana, $17.98 \mathrm{~m}$.

The $300 \mu \mathrm{m}$ scale-bar below figure 2 is for 1 to 5 specimens; the $100 \mu \mathrm{m}$ scale-bar below the figure 9 is for specimens 6 to 9 ; the $300 \mu \mathrm{m}$ scale-bar below the figure 10 is for specimens 10 to 16 ; the $100 \mu \mathrm{m}$ scale-bar below the figure 18 is for specimens 17 to 20 ; the $100 \mu \mathrm{m}$ scale-bar below the number 27 is for specimens 21 to 28.
} 


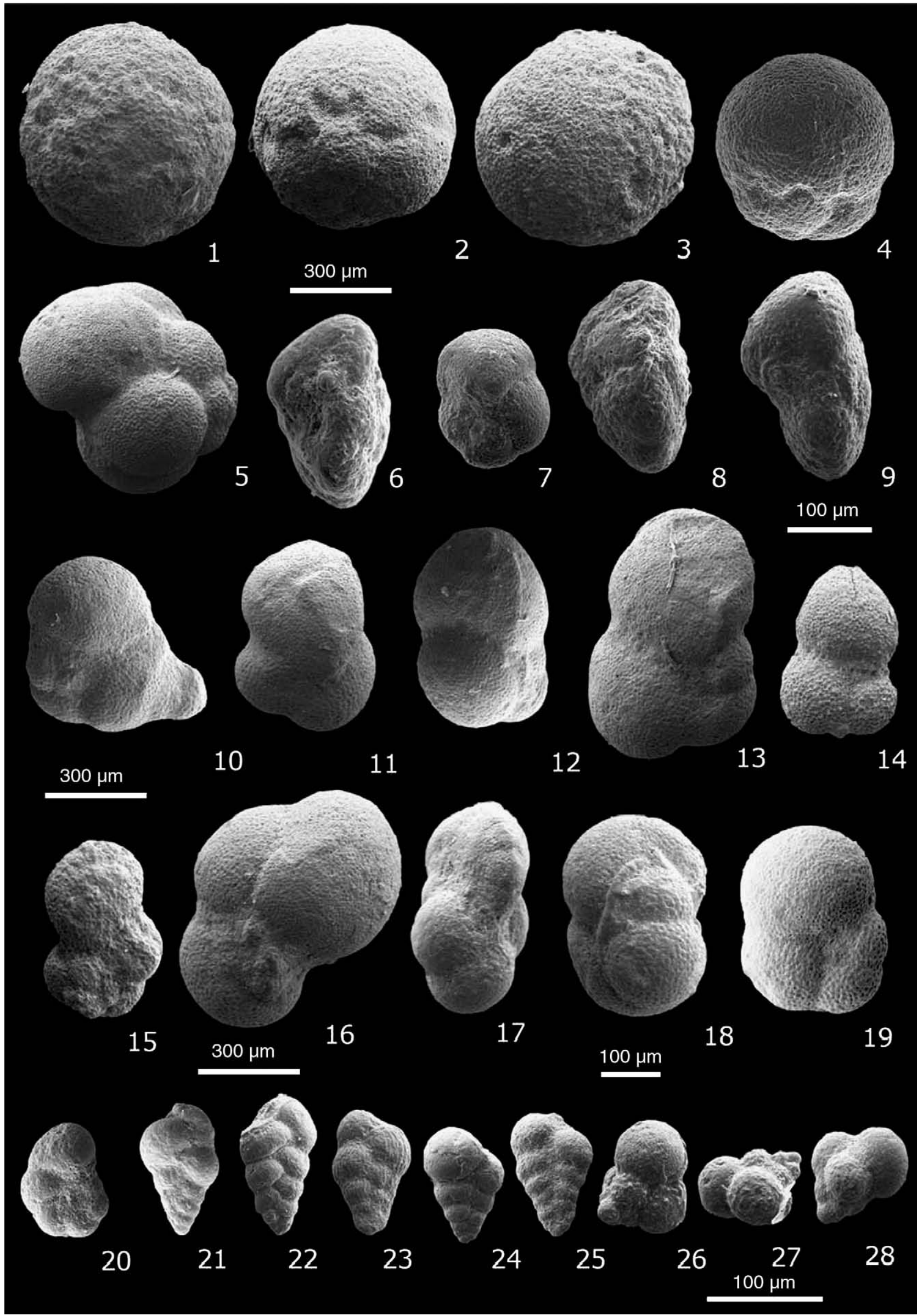

Please cite this article as: Luciani, V., et al., Ecological and evolutionary response of Tethyan planktonic foraminifera to the middle Eocene climatic optimum (MECO) from ..., Palaeogeography, Palaeoclimatology, Palaeoecology (2010), doi:10.1016/j.palaeo.2010.03.029 


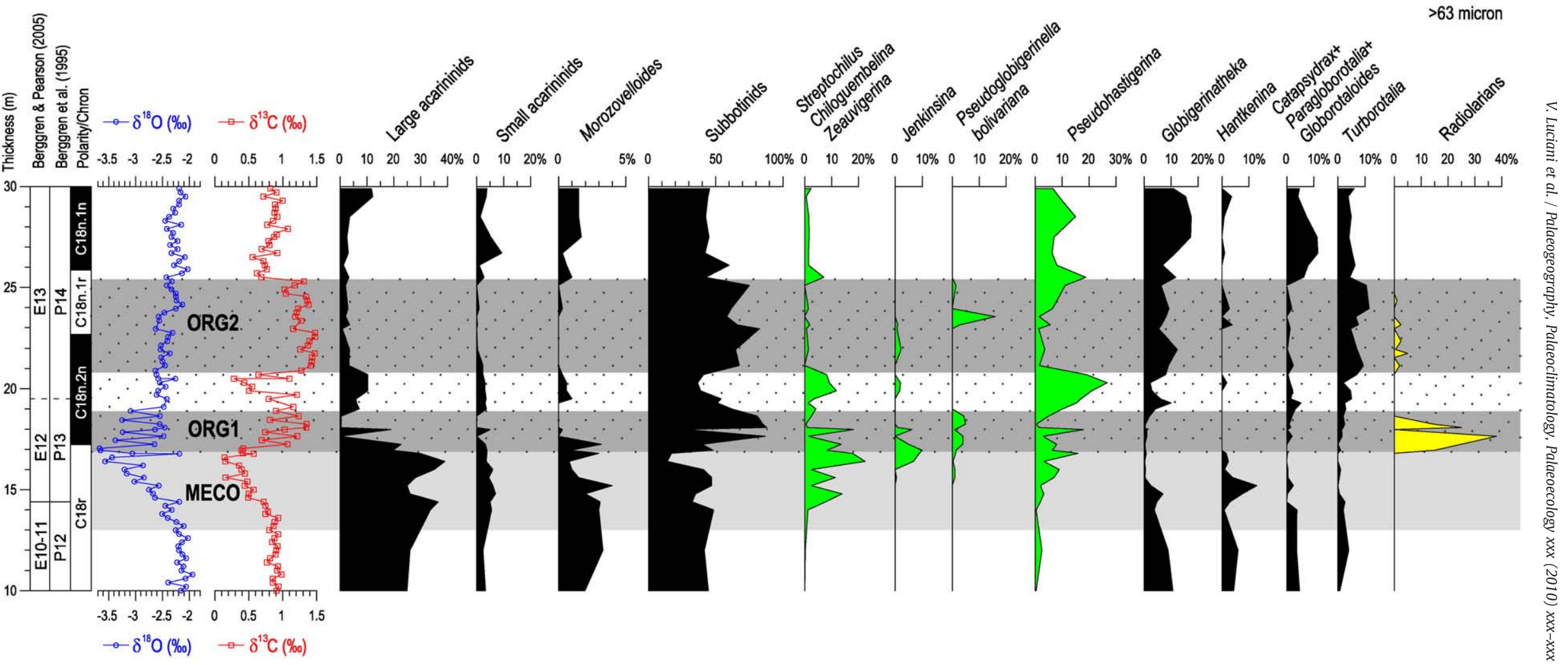

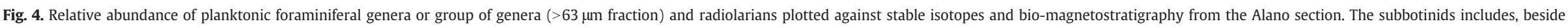

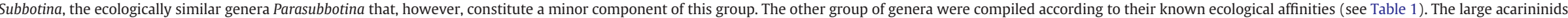

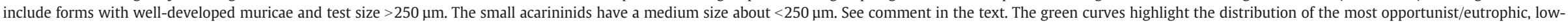
oxygen tolerant taxa among the planktonic foraminifera; the yellow curve underlines the abundances of the radiolarians. 


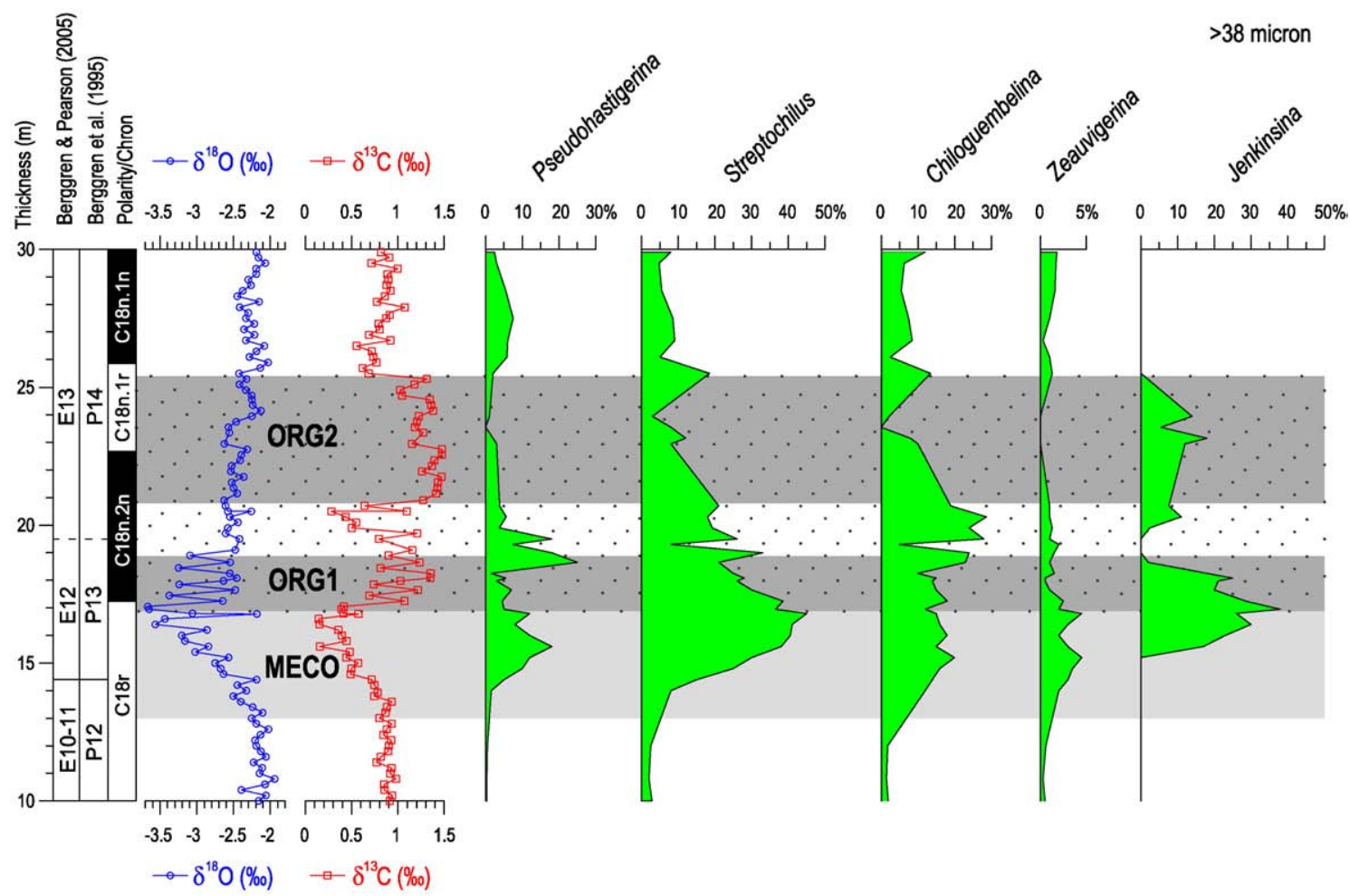

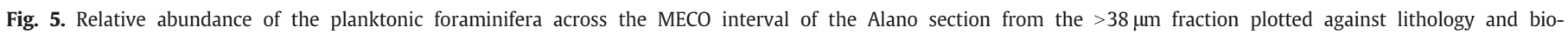
magnetostratigraphy.

unevenly distributed at Alano; it becomes consistently present (up to $3.7 \%$ in relative abundance) as the assemblages become subbotinidsdominated assemblages.

A temporary 'eclipse', almost complete, of the Hantkenina abundance is recorded within the ORG1. The genera Globigerinatheka, Turborotalia and Catapsydrax-group also virtually disappear in the lower part of the stable isotopes shifts $(\sim 13.5 \mathrm{~m}$ to $\sim 16.5 \mathrm{~m}$ ) (Fig. 4).

Specimens of planktonic foraminifera with giant-size (up to 700$800 \mu \mathrm{m})$ and aberrant tests are a characteristic feature of the sapropellike levels from the Alano section in the $>63 \mu \mathrm{m}$ fraction (Plate 1). These odd morphotypes may constitute altogether a significant part (from 20\% to $80-90 \%$ ) of the assemblage and exhibit various degrees of test deformations. Malformations affect several genera with a predominance of subbotininds and may consist in anomalous radialextension of the final chamber (relatively common), in aberrant chamber-like protrusions and irregular coiling (Plate 1). Benthonic foraminifera from the same levels of the Alano section show gigantism (e.g. large-sized Uvigerina) and test malformations as well (e.g. Bolivina antegressa Subbotina, 1953).

Other remarkable changes in planktonic assemblages coincide with the isotope shifts of the MECO and post-MECO intervals and consist in the appearance or marked increase in the abundance of small-sized forms such as Pseudohastigerina, the biserial Chiloguembelina, Streptochilus, Zeauvigerina, the triserial Jenkinsina and of the species Pseudoglobigerinella bolivarina. The relative abundances of these forms decline to lower values or disappear in the upper part of the studied section, above the ORG2. In addition, the ORG1 interval is relatively enriched in commonly pyritized radiolarians that constitute up to almost $40 \%$ of the total assemblage; they are also recorded, though with lower abundance, in the ORG2 (Fig. 4).

The $38 \mu \mathrm{m}$ to $63 \mu \mathrm{m}$ fraction partially comprises juveniles of both planktonic and benthonic foraminifera. This includes also small species belonging to Pseudohastigerina, Jenkinsina, Chiloguembelina, Streptochilus and Zeauvigerina (Fig. 5).
Before the pre-isotope excursion the small-sized forms were very scarce (altogether less than $5 \%$ of the total assemblages) and did not include Jenkinsina. At the beginning of the MECO event, the biserial forms consistently increase up to more than $60 \%$ of the assemblage in coincidence with the most negative values of $\delta^{18} \mathrm{O}$, at the base of C18n.2n, $40.13 \mathrm{Ma}$. In the MECO interval, the significant abundance of biserials is coupled with the increase of Pseudohastigerina, just followed by the appearance of Jenkinsina. Within the ORG1 interval, the small planktonic foraminiferal population show a peak of Jenkinsina (up to 40\%) and a relative decrease of Streptochilus and Pseudohastigerina (Fig. 5).

Across the MECO and initial post-MECO interval the lowest occurrence (LO, at $14.40 \mathrm{~m}$ ) and highest occurrence (HO, at $19.80 \mathrm{~m}$ ) of the index species Orbulinoides beckmanni was recorded. It must be remarked, however, that a correct identification of the HO of this species was complicated by the scarce abundance and poor preservation of planktonic foraminiferal assemblages within the sapropel-like interval. Beside the LO and $\mathrm{HO}$ of $\mathrm{O}$. beckmanni the record of the Alano section displays a number of other biohorizons strictly related to the MECO and post-MECO interval, that are reported in stratigraphic order below (Fig. 7):

a) The LOs of two species belonging to the Turborotalia cerroazulensis lineage, $T$. cerroazulensis and $T$. cocoaensis (the latter previously believed to appear later in the E13 zone, Pearson et al., 2006).

b) The HOs of the earlier representatives of the Turborotalia cerroazulensis lineage, $T$. frontosa and $T$. possagnoensis.

c) The $\mathrm{HO}$ of Globigerinatheka euganea.

c) The LO of the high-spired Subbotina gortanii (previously believed to appear later in the E13 zone, Pearson et al., 2006).

c) The LO of Globigerinatheka luterbacheri.

d) The LO of Turborotalia increbesens.

c) The $\mathrm{HO}$ of Globigerinatheka kugleri.

e) The HO of Pseudoglobigerinella bolivariana.

f) The HO of Jenkinsina colombiana. 


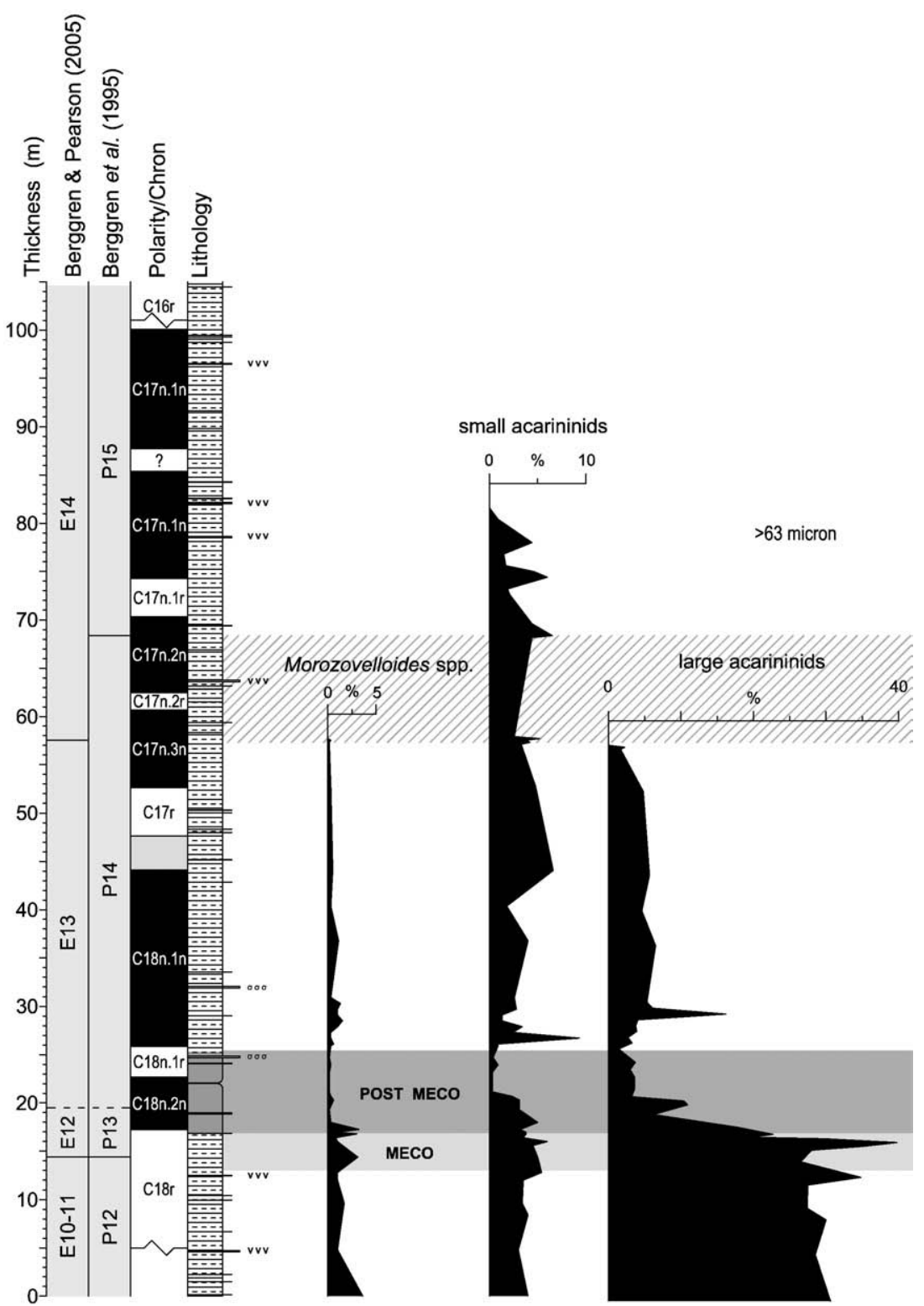

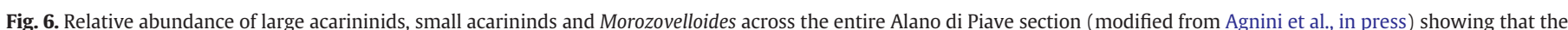

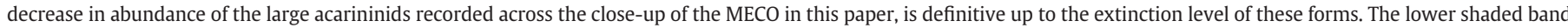

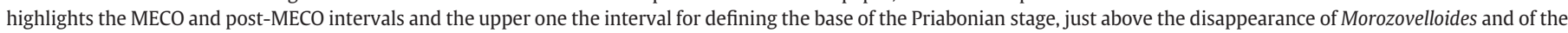
large acarininids.

\subsection{Dissolution within and below the organic-rich intervals}

The F-index shown in Fig. 3 displays a large variability throughout the interval investigated with the highest values (up to $>80 \%$ ) within the sapropel-like levels. Decrease of carbonate content, reduction in weight of the coarse fraction (Fig. 3) and a marked decrease of the planktonic/benthonic foraminiferal ratio (from $~ 90 \%$ to a minimum of $\sim 20 \%$ ) all occur in parallel to the increased shell fragmentation. Moreover, in many samples of the ORG1 and ORG2, the assemblages appear strongly depauperate and, in some cases, they are virtually composed exclusively by pyritized subbotinids (up to more than $80 \%$, Fig. 4). All these features are recognized in fossil assemblages as indicators of carbonate dissolution (e. g., Berger, 1970; Violanti et al., 1979; Conan et al., 2002, for a review). Between the ORG1 and ORG2 the preservation of foraminifera shows a significant improvement in the organic-poor interval ( $\sim 2 \mathrm{~m}$-thick) separating ORG1 and ORG2, where the $F$-index drops to values around $25 \%$.
An evident increase of $F$-index starts from $\sim 13 \mathrm{~m}$, below ORG1, within the organic-poor marls (Fig. 3), paralleling the gradual decrease in $\mathrm{CaCO}_{3}$ and stable isotopes values and reaching a peak at $\sim 45 \mathrm{~cm}$ below the base of ORG1.

\section{Discussion}

The changes in assemblages in both $>38 \mu \mathrm{m}$ and $>63 \mu \mathrm{m}$ fractions highlight a strict correlation with both the stable isotope curves and lithology becoming emphasized in correspondence to the sapropellike intervals (Figs. 4 and 5). Possible paleoenvironmental interpretations of these changes are based on the known paleoecological significance of the middle Eocene planktonic foraminifera and taking into account the available geochemical, lithological and mineralogical data of the Alano section.

Trophic and life strategies inferred for Paleogene taxa derive from several studies based on biogeographic distribution, environmental 


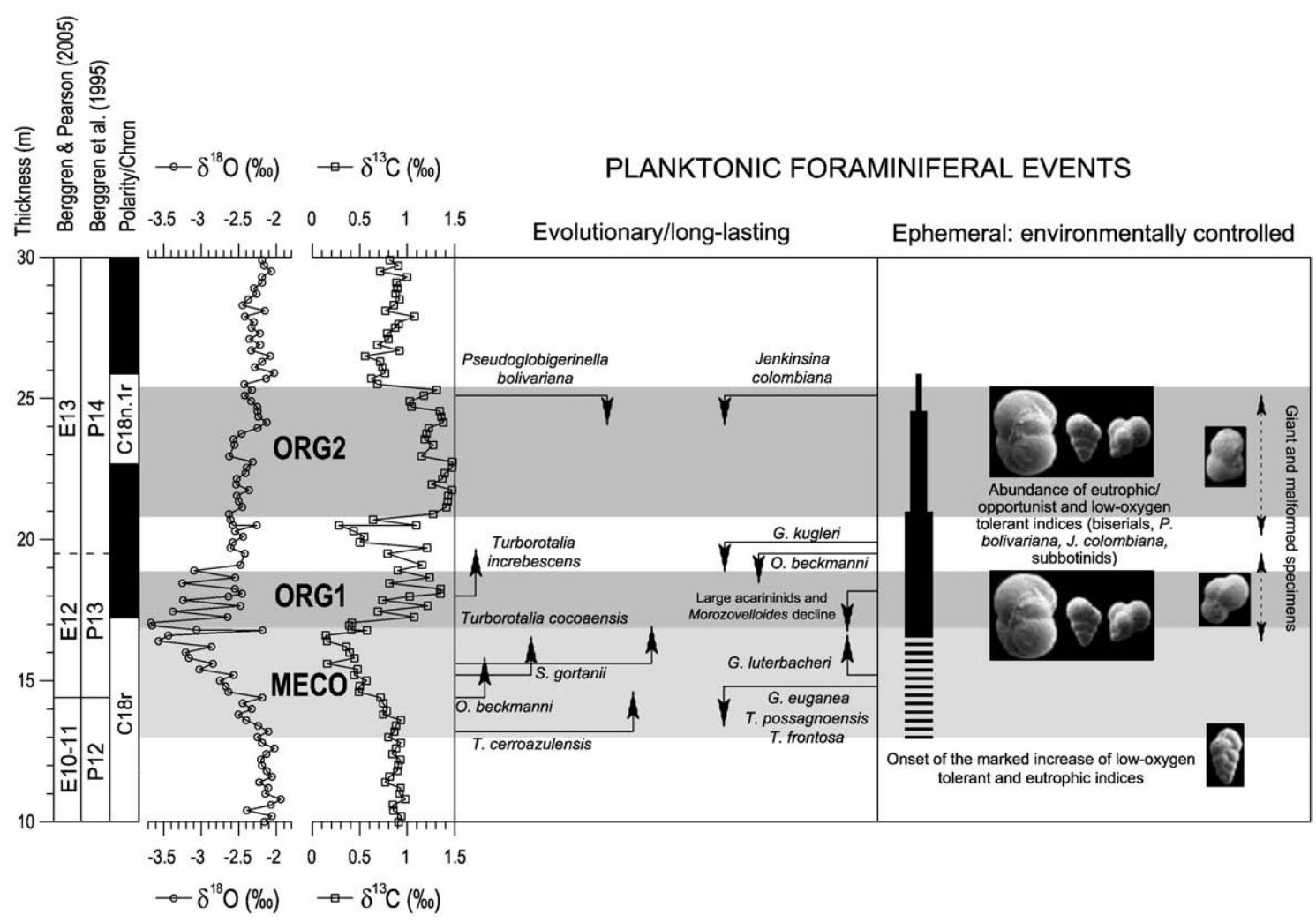

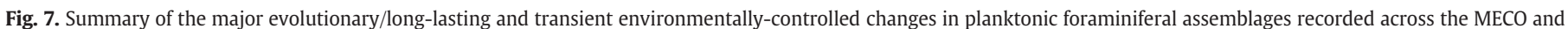
post-MECO at the Alano section plotted against the stable isotope curves. For discussion see the text. G. = Globigerinatheka; $0 .=$ Orbulinoides; . $=$ Subbotina; . $=$ Turborotalia .

inferences, stable oxygen and carbon-isotope gradients and their ecological implication, as extensively discussed in numerous papers and summarized in Table 1. The compositional and abundance changes of the planktonic foraminifera assemblages across the MECO interval allow us to interpret the environmental modifications recorded within the three major lithological and geochemical intervals of the section: 1) the pre-isotope excursion conditions (P12, E10/E11 zones), 2) the articulate interval of the isotope excursions that include the MECO and post-MECO with the deposition of the ORG1 and ORG2 (P13/E12, lower P14/E13 zones) and 3) the subsequent initial carbon isotope postrecovery interval above the ORG1 and ORG2.

\subsection{The large-acarininids decline at the MECO: a pre-extinction event}

A key event in the record of Cenozoic planktonic formanifera is the significant biotic turnover occurred in the latest middle Eocene. This consists of a notable reduction in the muricate planktonic foraminiferal species, the so-called extinction of the large acarininids and the evolutionary disappearance of the morozovellids. These groups dominated the tropical and subtropical assemblages in late Paleocene to middle Eocene and they have both previously been extensively employed as palaeoclimatic and biostratigraphic markers. Although conventionally attributed to a cooling event (e. g., Berggren, 1969; Keller, 1983; Boersma and Premoli Silva, 1991; Keller et al., 1992; Pearson, 1996), the extinction of these species has not been associated with any known abrupt cooling. Instead, eutrophication of surface waters and the demise of symbiotic relationships have thus been proposed as possible causal mechanisms of these extinctions (Wade, 2004).

Our data from the Alano section demonstrate that the first abrupt decline in abundance of the large acarininids and morozovellids took place well before their evolutionary extinction level at the Bartonian/ Priabonian transition (Fig. 5), being closely connected to the climatic change and paleoceanographic variations which occurred during the MECO.
5.2. Eutrophication and lowered oxygenation of the upper water column during the MECO and post-MECO intervals

It is commonly accepted that Jenkinsina, Pseudoglobigerinella bolivarina, Pseudohastigerina, and biserial forms such Chiloguembelina, Streptochilus and Zeauvigerina are among the generalist/opportunist eutrophic-index species. Furthermore, the biserial forms are considered to be tolerant of low-oxygen conditions (Table 1). Specifically, the planktonic foraminiferal genus Jenkinsina, characterized by triserial chamber arrangement, small size and smooth-walled test (Pearson et al., 2006) is morphologically very similar to the Cretaceous-lowest Paleogene Guembelitria, that thrived in the aftermath of the $K-T$ boundary (e., g., Smit, 1982; Keller et al., 1995; Keller and Pardo, 2004), and to the living Gallitellia. The strict morphological similarity with these triserial forms suggests similar ecological behaviour, even if paleobiological information on Jenkinsina cannot be directly inferred, since stable isotope data are not yet available. Gallitellia is a surface-dweller known as a tracer of high runoff, environmental unstability and upwelling conditions (e. g., Kroon and Nederbragt, 1990; Kimoto et al., 2009). Recently, Smart and Thomas (2006, 2007) interpreted the Miocene Streptochilus as an opportunist form with a similar ecological behaviour. In addition, Pseudoglobigerinella bolivarina is exclusively found in high-productivity/upwelling areas (Pearson et al., 2006).

The arrival and/or the marked increase in abundance of the index species mentioned above across the MECO and post-MECO intervals strongly suggests an environmental shift towards an increased eutrophication of the surface waters. The changes observed in planktonic foraminiferal assemblages thus suggest that the intervals of maximum nutrient influx in surface waters coincide with the deposition of the sapropel-like levels. Specifically, in the ORG1, peaks of radiolarians (eutrophic indices, e.g. Hallock, 1987) are accompanied by peaks of Jenkinsina and P. bolivariana (Fig. 4). The eutrophication signal is preceded by a marked increase of the biserial forms. This 


\section{Table 1}

Simplified scheme showing the inferred life strategies and depth ranking of middle Eocene planktonic foraminifera derived from latitudinal distribution, environmental inferences (morphology and biogeographic distribution) and stable isotope data. Data are according to (among others): Douglas and Savin, 1978; Boersma et al., 1987; Premoli Silva and Boersma, 1989; D'Hondt et al., 1994; Bralower et al., 1995; Lu and Keller, 1996; Corfield and Norris, 1998; Kelly, 1999; Quillévéré and Norris, 2003; Dutton et al., 2005 Pearson et al., 2006; Coxall et al., 2007; Luciani et al., 2007, this paper.
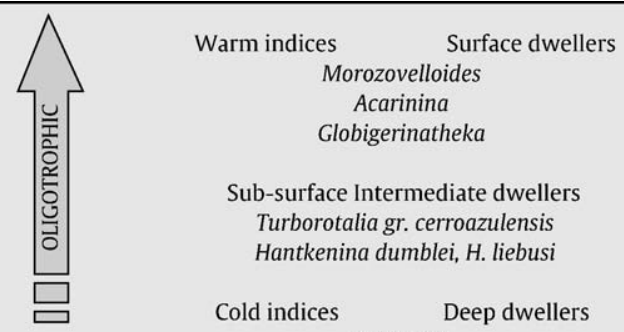

Globigerinatheka Surface dwellers

Sub-surface Intermediate dwellers Turborotalia gr. cerroazulensis Hantkenina dumblei, H. liebusi

Cold indices Deep dwellers Subbotina Parasubbotina Paragloborotalia Globorotaloides Catapsydrax Low-oxygen tolerant generalist/opportunist forms
Chiloguembelina Zeauvigerina Pseudohat Streptochilus Chiloguembelina Zeauvigerina Pseudohastigerina Higly eutrophic/opportunists Jenkinsina Pseudoglobigerinella bolivariana

suggests lowered oxygen conditions and/or an expanded oxygen minimum zone (OMZ) in the near-surface waters and the onset of an environmental eutrophication. The tendency to a low-oxygenated upper water column is supported by the concurrent increase of hantkeninids (Fig. 4). A rise in temperature (e.g., Bohaty and Zachos, 2003; Bohaty et al., 2009) related to this event could have decreased the solubility of oxygen and, at the same time, the enhanced photosynthetic activity in surface waters favoured a decrease in oxygen content in subsurface waters. An increase in the relative proportion of detrital material, synchronous with $\delta^{18} \mathrm{O}$ peak conditions, suggest that terrestrially derived nutrients, rather than upwelling, were the most likely source for the productivity increase (Spofforth et al., in press). An accelerated hydrological cycle forced by the intense warming may have caused increased run-off.

Changes in distribution and abundance of the small fraction genera indicate, according to their ecological significance (Fig. 5, Table 1), an unstable eutrophic environment confirming the interpretation above.

The 'eclipse' of the relatively specialized Globigerinatheka, Turborotalia, Catapsydrax and Hantkenina, if not related to dissolution (see below), can be associated to the transient environmental perturbation linked to the MECO (Fig. 4). It may have caused a temporary reduction of the planktonic foraminifera ecological niches in the upper part of the water column thus excluding the meso-oligotrophic assemblages.

\subsection{ORG1 and ORG2 intervals: subbotinid dominated or dissolution-controlled assemblages?}

As previously discussed, within the ORG1 and ORG2 intervals more than one indication warns against the possibility that carbonate dissolution could deeply affect the pristine sedimentary record.

Question arises on how to evaluate the actual role of this process and to what extent the observed pattern in planktonic foraminiferal assemblages at Alano was related to differential-dissolution artefacts rather than to a primary ecological signal.

Petrizzo et al. (2008) consider fragments of test at genera level as effective tool to distinguish primary signals from differentialdissolution effects. Results from their study on equatorial Pacific Ocean assemblages from the latest Paleocene to initial middle Eocene, designate the cold deep-dwelling subbotinids as the most dissolution- susceptible genus with respect to the muricate, warm surfacedwellers Morozovella and Acarinina, previously believed to be the most dissolution-prone forms. Therefore, any Paleogene assemblages affected by extensive dissolution are expected to be impoverished in the most dissolution-susceptible subbotinids. In contrast, the sapropel-like intervals of the Alano section with the highest fragmentation index display the largest relative percentages of subbotinids (Fig. 4). The intention to evaluate the abundance of test fragments for each genus, according to Petrizzo et al. (2008), is partly inhibited at Alano due to the planktonic foraminiferal preservation not as excellent as that of the ODP Sites, thus hampering in many cases a correct discrimination. On the other hand, in the Alano samples where this calculation was possible, the numbers of Subbotina fragments almost equal those of Acarinina with a very small presence of turbototalids and an even more negligible Morozovelloides fragments. We might consequently conclude that dissolution affected rather equally the plantkonic assemblages. It is possible that middle Eocene species of Subbotina here investigated were more robust forms and less prone to dissolution than the older ones investigated by Petrizzo et al. (2008). The apparent lack of one particularly dissolution-prone genus through ORG1 and ORG2 thus point out for assemblages essentially environmentally controlled. However, the presence/dominance of subbotinids within the sapropel-like intervals deserves an explanation. A marked shift towards an enhanced eutrophication of the upper part of the water column, supported by several other evidences discussed in the previous paragraphs, appears as a plausible justification. The decrease in temperature following the peak warming conditions does not appear to have directly influenced the increase of the relatively cold subbotininds because it is whether real - not permanent. On the other hand, the temporary entrance within these intervals of probable dissolution of new genera such as Jenkinsina and Pseudoglobigerinella (Figs. 4 and 5) and the consistent increase among the subbotinid-group of the previously scattered Parasubbotina griffinae, typical of high-productivity Eocene environments, are indisputably a genuine ecological signal. In conclusion, several lines of evidence support the idea that the ecological control on planktonic foraminiferal assemblages through the MECO event was not entirely obscured by carbonate dissolution. Nevertheless, as our foraminiferal record shows productivity increases during this interval, we would expect an increase in organic carbon rain rate and re-mineralization in a still oxygenated water column. This may have lowered local seawater/porewater $\mathrm{pH}$ and caused some of the dissolution signal seen here.

A special consideration merits the increase of dissolution that precedes the ORG1 deposition and parallels the isotope shifts, $\sim 45 \mathrm{~cm}$ below the base of ORG1 (Fig. 3). Dissolution in carbonate during the MECO has been recorded in ODP-IODP records and linked to a temporary rise of the $\mathrm{CCD} / \mathrm{lys}$ socline due to the amplified contribution of $\mathrm{CO}_{2}$ (Bohaty et al., 2009). It must be underlined, however, that such interpretation for the Alano section should imply a huge rise of the CCD/lysocline, considering that the lower $2 / 3$ of the section was likely deposited in a middle-bathyal setting, probably shallower than $1000 \mathrm{~m}$ (Agnini et al., in press). Further studies on Tethyan CCD in the Eocene interval will help to verify this hypothesis.

\subsection{Giant and malformed planktonic foraminifera within the ORG1 and ORG2: signals of stressed environment}

Fossil and recent foraminiferal tests showing morphological abnormalities have long been reported from highly stressed environments. Remarkably, oversize specimens of planktonic foraminifera exhibiting radial elongation of chambers were observed from the Paleocene Eocene Thermal Maximum (PETM) from the nearby Forada section (Venetian Pre-Alps, northern Italy), both among the so-called excursion-taxa acarininids and among other genera, included the subbotinids. The occurrence of odd forms has been related to the 
striking environmental perturbation during the PETM event (Luciani et al., 2007). Chamber elongation is a recurring morphological character in Cretaceous and Cenozoic planktonic foraminiferal evolution, commonly interpreted as an adaptation to poorly oxygenated and/or eutrophic environments (see reviews in Coccioni et al., 2006; Coxall et al., 2007). Abnormalities and gigantism in benthonic foraminifera in the present oceans have been attributed to eutrophication as well (Ballent and Carignano, 2008). Consequently, we can hypothesize that the planktonic foraminifera from the Alano section may have developed different life strategies by adopting abnormal and oversize morphological modifications to tolerate the temporary exceptionally stressed environmental conditions that followed the MECO, principally related to eutrophic and poorly oxygenated waters. The prominent increase in abundance of eutrophic and low-oxygen-tolerant indices, both in $>63 \mu \mathrm{m}$ and $>38 \mu \mathrm{m}$ fractions strongly support this hypothesis (Figs. 4 and 5). However the hantkeninids, considered to be low-oxygen tolerant as well (e. g., Coxall et al., 2007), unexpectedly decrease in abundance in the sapropel-like levels where subbotinids with radially-elongated chambers occur. If this reduction is authentic and not dissolution-controlled, it suggests a more complex scenario that involved other environmental parameters. Nevertheless, test deformation in both modern and ancient foraminiferal assemblages is considered to be distinctive of extreme environmental conditions characterized by a number of severe stresses, beside overabundance of food and low-oxygen content, including changes in salinity, $\mathrm{pH}$, temperature and pollution of trace elements (e. g., Boltovskoy et al., 1991; Yanko et al., 1998). A possible link with deformation and trace metal could be suggested at Alano by the increase of trace metal recorded in correspondence of the two sapropel-like intervals (Spofforth et al., in press) where these deformed specimens are recorded. Cases of morphological abnormalities are also documented when water acidification partially dissolve calcitic tests that successively, when higher values of $\mathrm{pH}$ are restored, may develop deformations during the shell reconstruction (e. g., Debenay et al., 2001; Geslin et al., 2002; Le Cadre et al., 2003). Changes in geochemistry of marine waters likely occur within the sapropel-like levels of the post-MECO at Alano, as previously discussed.

Other examples of exceptionally giant/deformed planktonic foraminiferal ecophenotypes are reported from latest Cenozoic Mediterranean sapropels where malformed Truncorotalia truncatulinoides and oversize Orbulina universa have been observed (Kidd et al., 1978). Atypical specimens up to $650 \mu \mathrm{m}$ in size attributed to Globigerina ciperoensis have been discovered in sediments from the Oligocene of the Haute-Savoie (France) and referred to a low-oxygenated marine environment that received substantial supplies of organic material (Ujetz and Wernli, 1994).

The benefits of large size in planktonic foraminifera may include an improved ability to capture prey, the possibility to ward off predators, greater reproductive success, and a better regulation of metabolism (e. g., Stanley, 1973; Calder, 1984). Additionally, ecological and physiological evidences indicate a positive correlation between test size and increasing water temperature (Schmidt et al., 2004).

Considering the evidence from literature and the Alano record, we suppose that the large-sized forms observed in our section benefited from a period of marked increase in the flux of organic matter and of reduced competition in low-oxygen conditions.

\subsection{Post-MECO cooling: evidences from the planktonic foraminifera}

The main ecological response to the MECO warming appears essentially as a pronounced shift to opportunist eutrophic planktonic foraminiferal assemblages, as discussed in the previous paragraphs and as an only moderate increase of the warm-indices, such as the large acarininids. The influence of the intense warmth appears therefore to have indirectly affected the assemblages.

The major permanent modification recorded in the studied area involves the warm-indices, large-sized muricates that decline in abundance just after the $\delta^{18} \mathrm{O}$ negative peak and never recover above it. The slight increase of the cold, deep-dweller Catapsydrax-group above the main shift of the $\delta^{18} \mathrm{O}$ curve could be related to the definitive return to the cooling trend of the middle-late Eocene after the MECO. A minor increase of relatively cool and temperate groups, as pseudohastigerinids, Globigerinatheka and Turborotalia is evident in the post-event assemblages as well. In the small-sized assemblages the abundances of the biserial Streptochilus and Chiloguembelina and of Pseudohastigerina are greater than in the pre-event.

\subsection{Reading the organic carbon burial and carbon-isotope curve through the planktonic foraminiferal record}

Our high-resolution quantitative planktonic foraminiferal data reveal pronounced and complex changes indicating a strong environmental perturbation that parallels the variations of the stable isotope curves. These features may provide a supplementary useful tool to interpret the organic carbon burial and carbon-isotope curve from the Alano section.

The preservation of organic carbon in rocks and sediments is still the focus of much debate, trying to explain both the formation of the Cretaceous black shales (Schlanger and Jenkyns, 1976) and late Cenozoic sapropels (Kidd et al., 1978). Two main hypotheses, stagnation $v s$ productivity, have been proposed during the past years (see Rohling, 1994 for an overview). The environmental scenario inferred from the planktonic foraminiferal assemblages at Alano suggests that the enhanced marine productivity was the prevailing mechanism for the post-MECO organic carbon accumulation at this site. Although this mechanism appears to prevail, it may be likely coupled with an increase in water column stratification, due to the input of fresh waters as a consequence of the enhanced hydrological cycle, favouring low $\mathrm{O}_{2}$ conditions and preservation of organic matter. A well-developed OMZ is indeed recorded by biotic indications in the upper water column by planktonic foraminiferal assemblages (high abundance of the lowoxygen tolerant indices). Dysoxic conditions at the sea floor could be inferred by marked changes in benthic foraminiferal communities, that is an increase in the abundance of Uvigerina and some other triserial and biserial taxa (e.g. bolivinids). These faunas are typically found in $\mathrm{O}_{2}$ depleted, organically enriched settings (Gooday, 2003). Further evidence for dysoxic bottom water conditions comes from the increase in sulphur and redox-sensitive trace metals, very low concentrations of Mn and the occurrence of pyrite (Spofforth et al., in press). In addition, our record gives clear evidence that the increased productivity was predominantly responsible for the heavier isotope signal at this locality in the ORG1 and ORG2, besides the burial of light carbon isotopes in the organic matter.

Although the MECO warming event appears to be recorded worldwide by pronounced changes of the $\delta^{13} \mathrm{C}$ and $\delta^{18} \mathrm{O}$ values its nature is still enigmatic. The synchronicity of global warming and deepwater acidification at the MECO has been considered as evidence of the fact that this event was linked to a transient increase in atmospheric $p \mathrm{CO}_{2}$, similarly to the earlier Paleogene hyperthermal events, though time and mechanisms were different (Tripati et al., 2005; Bohaty et al., 2009). An extensive degassing of $\mathrm{CO}_{2}$ from arc or intraplate hotspot volcanism or metamorphic decarbonation in orogenic belts have been proposed as sources (Kerrick and Caldeira, 1993; Bohaty et al., 2009). We interpret our planktonic foraminiferal changes to represent increases in marine productivity coincident with the lighter carbon signal. We, therefore, strongly suggest that the negative shift of the $\delta^{13} \mathrm{C}$ preceding the maximum warmth, records primarily an increase of $p \mathrm{CO}_{2}$ rather than a decrease in marine productivity.

A peculiar feature of the Alano carbon isotope curve is the rapid $\delta^{13} \mathrm{C}$ negative excursion recorded between the two organic-rich intervals that is not coupled with a negative shift in the $\delta^{18} \mathrm{O}$ curve. According to the planktonic foraminiferal data we can speculate that this negative excursion may represent a short-term interval where 
surface ocean productivity was lower as testified by the marked decrease or complete absence of the main eutrophic indices such as Jenkinsina, Pseudoglobigerinella and radiolarians. The consequent reduction in organic carbon burial may have contributed to the lighter isotope signal.

\subsection{Planktonic foraminiferal assemblages at the MECO: ephemeral and long-lasting evolutionary changes}

At Alano, all the previously described changes in the foraminiferal assemblages suggest a highly perturbed environment, characterized by eutrophy and intensification of the OMZ during the MECO and postMECO event. These changes are prominent though ephemeral, being temporally constrained to the transient environmental modifications induced by the MECO event. Besides these transitory alterations of the planktonic foraminiferal assemblages, a number of evolutionary events appear strictly related to the MECO interval (Fig. 7). Edgar et al. (2007b) and Luciani et al. (2009) have recently underlined the close correspondence of the total range of Orbulinoides beckmanni with the MECO. At Alano the range of this peculiar species is almost perfectly coincident with the major oxygen isotope excursion corroborating the hypothesis that it might represent for the MECO a sort of equivalent of the excursion taxa occurring during the PETM. Beside the evolution of $O$. beckmanni, the genus Globigerinatheka is also affected by a significant turnover as testified by the disappearances of G. euganea and G. kugleri (Fig. 7), and by the appearance of $G$. luterbacheri. All these events recorded at Alano are in agreement with the general ranges shown in Pearson et al. (2006). The evolutionary appearance of $T$. cerroazulensis and $T$. cocoaensis are positioned very close to the $\mathrm{LO}$ of $\mathrm{O}$. beckmanni and may represent additionally useful biostratigraphic events within this crucial interval. Finally, the definitive marked decline in abundance of the large acarininids and morozovelloidids, that became definitively extinct near the Bartonian/Priabonian boundary, is unexpectedly recorded at the end of the MECO (Fig. 6). Furthermore, according to Pearson et al. (2006) other events, involving species that are unevenly distributed or absent at Alano, appear to be confined across the MECO, such as the last occurrences of Hantkenina liebusi, Subbotina crociapertura, the first occurrences of Hantkenina primitiva, $H$. alabamensis, Catapsydrax globiformis and extinction of the low-latitude species Morozovelloides lehneri.

Most of the cited highest and lowest occurrences appear as genuine evolutionary appearances/disappearances even if further detailed data are needed as a confirmation, particularly for the highest occurrences events. Many modern features of foraminiferal test architectures seem evolved at about $40 \mathrm{Ma}$ (Sexton et al., 2006), giving additional evidence that the MECO might have influenced the planktonic foraminiferal evolution.

Apparently the greater number of events, consisting predominantly of potential evolutionary appearances, is confined in the earlier part of the warming episode (Fig. 7). The incoming species were characterized by different life strategies (surface-, intermediate- or deep-water dwellers), suggesting that an enhanced stratification, deriving from the warming and possibly from variations in salinity, may have induced a thermocline and nutricline displacement, thus producing new ecological niches. However, the evolutionary mechanisms inducing the apparent turnover during the MECO remain obscure. Recent genetic, molecular and ecological studies on living planktonic foraminifera increasingly suggest that paleoceanographic and paleoclimatic changes, modifying the vertical structure and seasonality of the surface pelagic water masses, induce repeated speciation, frequently cryptic, events (e. g., Norris, 2000; Kucera and Darling, 2002; Darling and Wade, 2008).

\section{Summary and conclusions}

The high-resolution investigation of the planktonic foraminifera from the Alano section of northern Italy represents a useful case- history recording the response to the MECO warming in the crucial Tethys area. The Alano record indicates that the intense warmth during the MECO led to a modification of the marine environment causing profound changes in biogeochemical cycles. In spite of some dissolution that affects the carbonate sediments at Alano through the MECO event, several lines of evidence suggest that changes in planktonic foraminiferal assemblages were essentially ecologically controlled. The strict correspondence of the recorded biotic changes with geochemistry and lithology reveals close cause-effect relationships between changes in environmental conditions and modifications of the assemblages.

The main results of this study can be summarized as follows:

(1) The most prominent consequence of the climatic variations during the MECO as recorded at Alano is a pronounced shift from relatively oligotrophic to eutrophic, opportunist, low-oxygen tolerant planktonic foraminiferal assemblages, symptomatic of increased nutrient input and surface ocean productivity. If we assume that modifications of planktonic foraminiferal paleoecological indices aid in evaluating the real intensity of the environmental perturbation, the higher percentage of opportunists across the lower organic-rich level may provide evidence that the environment was more stressed during its deposition with respect to the remaining part of the post-MECO interval. Albeit duration and pattern of warming clearly distinguish the early Paleogene hyperthermals from the MECO event and suggest diverse causal mechanisms, certain analogies exist in the biotic response (Luciani et al., 2007; Agnini et al., 2009). Specifically, in the studied setting the pronounced warming, that is the key character shared by all these events, prove to have caused eutrophication of surface waters, as a consequence of the modified, enhanced hydrological cycle.

(2) The environmental perturbation induced by the MECO, as recorded by changes in foraminiferal assemblages and lithology, lasted well after the event (defined as equivalent to the negative shift interval of the oxygen-isotope curve) and it corresponds to the entire $\sim 800-900 \mathrm{kyr}$ carbon-isotope perturbation. At Alano, the environmental recovery occurs when the stable isotope curves return near to the pre-event values.

(3) The planktonic foraminiferal record points out for an increase in marine productivity as the prevailing mechanism for the organic carbon accumulation at this site; a confirmation is also given by the entry of the eutrophic radiolarians in our record. The depleted $\mathrm{O}_{2}$ sea floor waters and the organic carbon burial following the peak of the MECO event, thus represent a response to the MECO warming.

(4) The presence of exceptionally large-sized planktonic foraminifera, generally subbotinids, within the organic-rich levels, is likely related with high-nutrient flows in low-oxygenated environment. The morphological abnormalities observed in several planktonic foraminiferal tests from the sapropel-like sediments, denote transient alterations in the ocean chemistry across the $\mathrm{MECO}$, including possible $\mathrm{pH}$ oscillations and increase in trace metal content.

(5) Our data clearly indicates that the negative shift of the $\delta^{13} \mathrm{C}$ characterizing the MECO was likely triggered by an increase of $p \mathrm{CO}_{2}$ rather than a decrease in marine productivity. In particular, the lightening of the carbon stable isotope preceding the maximum warmth is coupled at Alano with a marked increase of marine productivity that could have resulted in heavier $\delta^{13} \mathrm{C}$ values. The synchronicity of globally extensive warming and deep-water acidification at the MECO provide additional arguments that this event was linked to a transient increase in atmospheric $p \mathrm{CO}_{2}$ similarly to the earlier Paleogene hyperthermal events (Bohaty et al., 2009). We can suppose that the enhanced productivity of surface waters across the MECO 
and post-MECO might have been a mechanism for the $\mathrm{pCO}_{2}$ reduction and return to the general cooling trend after the event. The depleted $\mathrm{O}_{2}$ sea floor waters and organic carbon burial following the peak of the MECO, if representing a widespread response to the MECO warming, suggest that high sequestration of organic matter could have supported the decrease of $p \mathrm{CO}_{2}$ as well.

(6) Finally, several lines of evidence indicate that the MECO was associated to permanent changes in planktonic foraminiferal evolution beside the transient, ecologically controlled, variations. One of the most significant events is the irreversible decline of the symbiont-bearing, warm-indices large acarininids after the MECO. The causes of this persisting crisis, occurred about $2 \mathrm{Ma}$ before their extinction near the middlelate Eocene boundary, may include the enduring decrease in temperatures following the event and the consequent modification in the water column structure with reduction of ecological niches of the muricates and/or those of the muricate symbionts. An intriguing speculation may involve the changes in the $\mathrm{pCO}_{2}$ following the MECO that may have prejudiced the complex mechanism of the symbiosis process. The true mechanisms forcing evolution of life on Earth are still unexplained despite decades of research in evolution and represent a major challenge for modern scientists. It is unclear if predominantly biotic (the Red Queen hypothesis by van Valen, 1973) or physical factors (the stationary model by Stenseth and Maynard Smith, 1984) are more important in the initiation of speciation and extinction. The global climatic change and related paleoceanographic modifications at the MECO have apparently played a role in speciation and extinctions of planktonic foraminifera. The MECO event, driving Earth's climate through the critical transition from greenhouse to icehouse, appears therefore as a crucial interval in which the close interaction between global climate and biological evolution can be perceived.

\section{Acknowledgements}

Funding for this research was provided by MIUR/PRIN COFIN 2003, 2005 and 2007 (D. Rio). V. Luciani was also financially supported by FAR from Ferrara University. This paper greatly benefited from the constructive comments by two anonymous referees and by the Editor Thierry Corrège. Thanks are due to Lorenzo Franceschin for processing the samples. SEM images were acquired at the Centro di Microscopia Elettronica of the Ferrara University.

\section{Appendix A. List of planktonic foraminiferal cited taxa in alphabetic order}

Catapsydrax globiformis Blow and Banner, 1962

Chiloguembelina cubensis (Palmer, 1934)

Chiloguembelina ototara (Finlay, 1940)

Globigerina ciperoensis Bolli, 1954

Globigerinatheka euganea Proto Decima and Bolli, 1970

Globigernatheka kugleri (Bolli, Loeblich and Tappan, 1957)

Globigernatheka luterbacheri Bolli, 1972

Jenkinsina columbiana (Howe, 1939)

Hantkenina liebusi Shokhina, 1937

Hantkenina alabamensis Cushman, 1924

Hantkenina primitiva Cushman and Jarvis, 1929

Morozovelloides lehneri (Cushman and Jarvis, 1929)

Orbulina universa d'Orbigny, 1839

Orbulinoides beckmanni (Saito, 1962)

Parasubbotina griffinae (Blow, 1979)

Pseudoglobigerinella bolivariana (Petters, 1954)

Pseudohastigerina micra (Cole 1927)
Streptochilus martini (Pijpers, 1933)

Subbotina crociapertura Blow, 1979

Subbotina gortanii (Borsetti, 1959)

Turborotalia cerroazulensis (Cole, 1928)

Turborotalia cocoaensis (Cushman, 1928)

Turborotalia frontosa (Subbotina, 1953)

Turborotalia increbesens (Bandy, 1949)

Turborotalia possagnoensis (Toumarkine and Bolli, 1970)

Truncorotalia truncatulinoides (d'Orbigny, 1839)

Zeauvigerina zelandica Finlay, 1939

\section{References}

Agnini, C., Macrì, P., Backman, J., Brinkhuis, H., Fornaciari, E., Giusberti, L., Luciani, V., Rio, D., Sluijs, A., Speranza, F., 2009. An early Eocene carbon cycle perturbation at $\sim 52.5 \mathrm{Ma}$ in the Southern Alps: chronology and biotic response. Paleoceanography 24, PA2209. doi:10.1029/2008PA001649.

Agnini, C., Fornaciari, E., Giusberti, L., Grandesso, P., Lanci L., Luciani, V., Muttoni, G., Rio, D., Stefani, C., Pälike, H., Spofforth, D.J.A., in press. Integrated bio-magnetostratigraphy of the Alano section (NE Italy): a proposal for defining the middle-late Eocene boundary. GSA Bulletin.

Ballent, S.C., Carignano, A.P., 2008. Morphological abnormalities in Late Cretaceous and early Paleocene foraminifer tests (northern Patagonia, Argentina). Marine Micropaleontology 67, 288-296.

Berger, W.H., 1970. Planktonic Foraminifera: selective solution and the lysocline. Marine Geology 8, 111-138.

Berger, W.H., Bonneau, M.-C., Parker, F.L., 1982. Foraminifera on the deep-sea floor: lysocline and dissolution rate. Oceanologica Acta 5, 249-258.

Berggren, W.A., 1969. Rates of evolution in some Cenozoic planktonic foraminifera. Micropaleontology 15, 351-365.

Berggren, W.A., Pearson, P.N., 2005. A revised tropical to subtropical Paleogene planktonic foraminiferal zonation. Journal of Foraminiferal Research 35, 279-298.

Berggren, W.A, Kent, D.V., Swisher III, C.C., Aubry, M.-P., 1995. A revised Cenozoic geochronology and chronostratigraphy. In: Berggren, W.A., et al. (Ed.), Geochronology, Time Scales and Global Stratigraphic Correlation: Society for Sedimentary Geology Special Publication, 54, pp. 129-212.

Boersma, A., Premoli Silva, I., 1991. Distribution of Paleogene planktonic foraminiferaanalogies with the recent? Palaeogeography Palaeoclimatology, Palaeoecology 83, $29-48$.

Boersma, A., Premoli Silva, I., Shackleton, N., 1987. Atlantic Eocene planktonic foraminiferal biogeography and stable isotopic paleoceanography. Paleoceanography 2, 287-331.

Bohaty, S.M., Zachos, J.C., 2003. A significant Southern Ocean warming event in the late middle Eocene. Geology 31, 1017-1020.

Bohaty, S.M., Zachos, J.C., Florindo, F., Delaney, M.L., 2009. Coupled greenhouse warming and deep-sea acidification in the Middle Eocene. Paleoceanography 24, PA2207. doi:10.1029/2008PA001676,2009.

Boltovskoy, E., Scott, D.B., Medioli, F.S., 1991. Morphological variations in benthic foraminiferal tests in response to changes in ecological parameters: a review. Journal of Paleontology 65, 175-185.

Bosellini, A., 1989. Dynamics of Tethyan carbonate platform. In: Crevello, P.D., James, L.W., Sarg, J.F., Read, J.F. (Eds.), Controls on Carbonate Platform and Basin Platform: Society for Sedimentary Geology (SEPM) Special Publication, vol. 44, pp. 3-13.

Bosellini, F.R. Papazzoni, C.A. 2003. Palaeoecological significance of coral-encrusting foraminiferan associations: a case-study from the Upper Eocene of northern Italy. Acta Palaeontologica Polonica 48 (2), 279-292.

Bralower, T.J. Zachos, J.C. Thomas, E., Parrow, M. Paull, C.K., Kelly, D.C., Premoli Silva, I. Sliter, W.V., Lohmann, K.C., 1995. Late Paleocene to Eocene paleoceanography of the equatorial Pacific Ocean: stable isotopes recorded at Ocean Drilling Program Site 865, Allison Guyot. Paleoceanography 10, 841-865.

Broecker, W.S., Clark, E., 1999. $\mathrm{CaCO}_{3}$ size distribution: a paleocarbonate ion proxy? Paleoceanography 14 (5), 596-604.

Calder, W.A., 1984. Size, Function, and Life History. Harvard University Press, Cambridge, MA. 431 pp.

Cita, M.B., 1975. Stratigrafia della Sezione di Possagno. In: Bolli, H.M. (Ed.), Monografia Micropaleontologica sul Paleocene e l'Eocene di Possagno, Provincia di Treviso, Italia: Schweizerische Palaeontologische Abhandlungen, 97, pp. 9-33.

Coccioni, R., Luciani, V., Marsili, A., 2006. Cretaceous oceanic anoxic events and radially elongated chambered planktonic foraminifera: paleoecological and paleoceanographic implications. Palaeogeography, Palaeoclimatology, Palaeoecology 235, 66-92.

Conan, S.M.-H., Ivanova, E.M., Brummer, G.-J.A., 2002. Quantifying carbonate dissolution and calibration of foraminiferal dissolution indices in the Somali Basin. Marine Geology 182, 325-349.

Corfield, R.M., Norris, R.D., 1998. The oxygen and carbon isotopic context of the Paleocene-Eocene Epoch boundary. In: Aubry, M.-P., Lucas, S., Berggren, W.A. (Eds.), Late Paleocene-Early Eocene Climatic and Biotic Events in the Marine and Terrestrial Records. Columbia University Press, New York, pp. 124-137.

Coxall, H.K., Wilson, P.A., Pearson, P.N., Sexton, P.F., 2007. Iterative evolution of digitate planktonic foraminifera. Paleobiology 33 (4), 495-516.

D'Hondt, S., Zachos, J.C., Schultz, G., 1994. Stable isotopic signals and photosymbiosis in late Paleocene planktic foraminifera. Paleobiology 20, 391-406. 
Darling, K.F., Wade, C.M., 2008. The genetic diversity of planktic foraminifera and the global distribution of ribosomal RNA genotypes. Marine Micropaleontology 67, 216-238.

Debenay, J.-P., Geslin, E., Beck Eichler, B., Duleba, W., Sylvestre, F., Eichler, P., 2001. Foraminiferal assemblages in a hypersaline lagoon, Araruama (R.J.) Brazil. Journal of Foraminiferal Research 31, 133-151.

Douglas, R.G., Savin, S.M., 1978. Oxygen isotopic evidence for the depth stratification of Tertiary and Cretaceous planktic foraminifera. Marine Micropaleontology 3, 175-196.

Dutton, A., Lohmann, K.C., Leckie, R.M., 2005. Insights from the Paleogene tropical Pacific: foraminiferal stable isotope and elemental results from Site 1209, Shatsky Rise. Paleoceanography 20, PA3004. doi:10.1029/2004PA001098.

Edgar, K.M., Wilson, P.A., Sexton, P.F., Suganuma, Y., 2007a. No extreme bipolar glaciation during the main Eocene calcite compensation shift. Nature 448, 908-911.

Edgar, K.M., Sexton, P.F., Norris, R.D., Wilson, P.A., Gibbs, S.J., 2007b. Evolutionary response of planktic foraminifera to a pronounced global warming event $40 \mathrm{Myr}$ ago. Eos Trans. AGU, 88(52) Supplement, 2007, OS14A-03.

Geslin, E., Debenay, J.-P., Duleba, W., Bonetti, C., 2002. Morphological abniormalities of foraminiferal tests in Brazilian environments; comparison between polluted and non-polluted areas. Marine Micropaleontology 45, 151-168.

Gooday, A., 2003. Benthic foraminifera (Protista) as tools in deepwater palaeoceanography: environmental influences on faunal characteristics. Advances in Biology 46, $1-90$.

Hallock, P., 1987. Fluctuations in the trophic resource continuum: a factor in global diversity cycles? Paleoceanography 2, 457-471.

Hancock, H.J.L., Dickens, G.R., 2005. Carbonate dissolution episodes in Paleocene and Eocene sediment, Shatsky Rise, west-central Pacific. In: Bralower, T.J., Premoli Silva, I., Malone, M.J. (Eds.), Proc. ODP, Sci. Results, vol. 198. [Online]. Available from World Wide Web: http://www-odp.tamu.edu/publications/198_SR/116/116.htm.

Jovane, L., Florindo, F., Coccioni, R., Dinarès-Turell, J., Marsili, A., Monechi, S., Roberts, A.P. Sprovieri, M., 2007. The middle Eocene climatic optimum event in the Contessa Highway section, Umbrian Apennines, Italy. Geological Society of America Bulletin 119, 413-427.

Keller, G., 1983. Paleoclimatic analyses of middle Eocene through Oligocene planktic foraminiferal faunas. Palaeogeography, Palaeoclimatology, Palaeoecology 43, 73-94.

Keller, G., Pardo, A., 2004. Disaster opportunist genus Guembelitridae: index for environmental catastrophes. Marine Micropaleontology 53, 83-116.

Keller, G., MacLeod, N., Barrera, E., 1992. Eocene - Oligocene faunal turnover in planktic foraminifera, and Antarctic glaciation. In: Prothero, D.R., Berggren, W.A. (Eds.), Eocene- Oligocene Climatic and Biotic Evolution. Princeton University Press, New Jersey, pp. 218-244.

Keller, G., Li, L., MacLeod, N., 1995. The Cretaceous/Tertiary boundary stratotype section at El Kef, Tunisia: how catastrophic was the mass extinction? Palaeogeography, Palaeoclimatology, Palaeoecology 119, 221-254.

Kelly, D.C., 1999. Ecospace portioning during the late Paleocene radiation of the planktonic foraminifera genus Morozovella: inference from stable isotopes. Geological Society of America, Abstract with Programs 31 (7), 122.

Kennett, J.P., Stott, L.D., 1991. Abrupt deep-sea warming, palaeoceanographic changes and benthic extinctions at the end of the Paleocene. Nature 353, 225-229.

Kerrick, D.M., Caldeira, K., 1993. Paleoatmospheric consequences of $\mathrm{CO}_{2}$ released during early Cenozoic regional metamorphism in the Tethyan orogen. Chemical Geology 108, 201-230. doi:10.1016/0009-2541(93)90325-D.

Kidd, R.B., Bernoulli, D., Garrison, R.E., Fabricius, F.H., Mélières, F., 1978. Lithologic findings of DSDP Leg 42A, Mediterranean Sea. In: Hsu, K.J., Montadert, L. (Eds.), Initial Reports of the Deep Sea Drilling Project, vol. 42. US Government Printing O/ce, Washington, DC, pp. 1079-1094. Part 1.

Kimoto, K., Ishimura, T., Tsunogal, U., Itaki, T., Ujilé, Y., 2009. The living triserial planktic foraminifer Gallitellia vivans (Cushman): distribution, stable isotopes, and paleoecological implications. Marine Micropaleontology 71 (1-2), 71-79.

Kroon, D., Nederbragt, A.J., 1990. Ecology and paleoecology of triserial planktic foraminifera. Marine Micropaleontology 16, 25-38.

Kucera, M., Darling, K.F., 2002. Cryptic species of planktonic foraminifera: their effect on palaeoceanographic reconstructions. Philosophical Transactions of the Royal Society of London A 360, 695-718.

Le Cadre, V., Debenay, J.-P., Lesourd, M., 2003. Low pH effects on Ammonia beccarii test deformation: implications for using test deformations as a pollution indicator. Journal of Foraminiferal Research 33, 1-9.

Lourens, L.J., Sluijs, A., Kroon, D., Zachos, J.C., Thomas, E., Röhl, U., Bowles, J., Raffi, I. 2005. Astronomical pacing of late Palaeocene to early Eocene global warming events. Nature 435, 1083-1087.

Lu, G., Keller, G., 1996. Separating ecological assemblages using stable isotope signals: late Paleocene to early Eocene planktic foraminifera, DSDP Site 577. Journal of Foraminiferal Research 26, 103-112.

Luciani, V., Lucchi Garavello, A.M., 1986. Biostratigrafia del Paleogene pelagico del Bacino del Sarca (Trentino meridionale). Studi tridentini Scienze Naturali, Acta Geologica 62, 19-70.

Luciani, V., Giusberti, L., Agnini, C., Backman, J., Fornaciari, E., Rio, D., 2007. The PaleoceneEocene Thermal Maximum as recorded by Tethyan planktonic foraminifera in the Forada section (northern Italy). Marine Micropaleontology 64, 189-214.

Luciani, V., Agnini, C., Fornaciari, E., Giusberti, L., Rio, D., Spofforth, D.J.A., Pälike, H., 2009. Ecological and evolutionary response of Tethyan planktonic foraminifera to the Middle Eocene Climatic Optimum (Alano di Piave section, NE Italy) Geophysical Research Abstracts, Vol. 11, EGU2009-10464-2, 2009 EGU General Assembly 2009.

Martini, E., 1971, Standard Tertiary and Quaternary calcareous nannoplankton zonation. In: Farinacci, A., ed., Proceedings of the 2nd Planktonic Conference, 2 Ed. Tecnoscienza, Roma, p. 739-785.
Miller, K.G., Wright, J.D., Fairbanks, R.G., 1991. Unlocking the ice house: OligoceneMiocene oxygen isotopes, eustacy and margin erosion. Journal of Geophysical Research 96, 6829-6848.

Nicolò, M.J., Dickens, G.R., Hollis, C.J., Zachos, J.C., 2007. Multiple early Eocene hyperthermals: their sedimentary expression on the New Zealand continental margin and in the deep sea. Geology 35, 699-702.

Norris, R.D., 2000. Pelagic species diversity, biogeography and evolution. In: Erwin, D.M., Wine, S.L. (Eds.), Deep Time: Paleobiology's Perspective: Supplement of Paleobiology, 26, pp. 237-258.

Okada, H., Bukry, D., 1980. Supplementary modification and introduction of code numbers to the low-latitude coccolith biostratigraphic zonation (Bukry, 1973; 1975). Marine Micropaleontology 5, 321-325.

Pearson, P.N., 1996. Cladogenetic, extinction and survivorship patterns from a lineage phylogeny: the Paleogene planktonic foraminifera. Micropaleontology 42, 179-188.

Pearson, P.N., Olsson, R.K., Hemblen, C., Huber, B.T., Berggren, W.A. (Eds.), 2006 Atlas of Eocene Planktonic Foraminifera: Cushman Special Publication, vol. 41, p. 513

Petrizzo, M.R., Leoni, G., Speijer, R.P., De Bernardi, B., Felletti, F., 2008. Dissolution susceptibility of some Paleogene planktonic foraminifera from ODP Site 1209 (Shatsky Rise, Pacific Ocean). Journal of Foraminiferal Research 38, 357-371.

Premoli Silva, I., Boersma, A., 1989. Atlantic Paleogene planktonic foraminifera bioprovincial indices. Marine Micropaleontology 14, 357-371.

Quillévéré, F., Norris, R., 2003. Ecological development of acarininids (planktonic foraminifera) and hydrographic evolution of Paleocene surface waters. In: Wing, S.L. Gingerich, P.D., Schmitz, B., Thomas, E. (Eds.), Causes and consequences of globally warm climates in the Early Paleogene: Geological Society of America Special Paper vol. 369, pp. 223-238.

Rohling, E.J., 1994. Review and new aspects concerning the formation of eastern Mediterranean sapropels. Marine Geology 122, 1-28.

Schlanger, S.O., Jenkyns, H.C., 1976. Cretaceous oceanic anoxic events: causes and consequences. Geol. Mijnb. 55, 179-184.

Schmidt, D.N., Thierstein, H.R., Bollmann, J., 2004. The evolutionary history of size variation of planktic foraminiferal assemblages in the Cenozoic. Palaeogeography, Palaeoclimatology, Palaeoecology 212, 159-180.

Sexton, P.F., Wilson, P.A., Norris, R.D., 2006. Testing the Cenozoic multisite composite $\delta^{18} \mathrm{O}$ and $\delta^{13} \mathrm{C}$ curves: new monospecific Eocene records from a single locality, Demerara Rise (Ocean Drilling Program Leg 207). Paleoceanography 21 (2), PA2019.

Smart, C.W., Thomas, E., 2006. The enigma of Early Miocene biserial planktic foraminifera. Geology 34, 1041-1044. doi:10.1130/G23038A.1.

Smart, C.W., Thomas, E., 2007. Emendation of the genus Streptochilus Brönnimann and Resig 1971 (Foraminifera) and new species from the lower Miocene of the Atlantic and Indian Oceans. Micropaleontology 53 (1,2), 73-104.

Smit, J., 1982. Extinction and evolution of planktonic foraminifera after a major impact at the Cretaceous/Tertiary boundary. In: Silver, L.T., Schultz, P.H. (Eds.), Geological Implications of Impacts of large Asteroids and Comets on the Earth: Special PaperGeological Society of America, vol. 190, pp. 329-352.

Spofforth, D.J.A., Agnini, C., Pälike, H., Rio, D., Fornaciari, E., Giusberti, L., Luciani, V., Lanci, L., Muttoni, G., 2010. Organic carbon burial following the Middle Eocene Climatic Optimum (MECO) in the central-western Tethys. Paleoceanography, DOI:10.1029, in press

Stanley, S.M., 1973. An explanation for Cope's rule. Evolution 27 (1), 1-26.

Stap, L., Sluijs, A., Thomas, E., Lourens, L., 2009. Patterns and magnitude of deep sea carbonate dissolution during Eocene Thermal Maximum 2 and H2, Walvis Ridge, southeastern Atlantic Ocean. Paleoceanography 24, PA1211. doi:10.1029/2008PA001655.

Stenseth, N.C., Maynard Smith, J.M., 1984. Coevolution in ecosystems - Red Queen evolution or stasis. Evolution 38 (4), 870-880.

Toumarkine, M., Luterbacher, H., 1985. Paleocene and Eocene planktonic foraminifera. In: Bolli, H.M., Saunders, J.B., Perch Nielson, K. (Eds.), Plankton Stratigraphy. Cambridge University Press, pp. 87-153.

Trevisani, E., 1997. Stratigrafia sequenziale e paleogeografia del margine orientale del Lessini Shelf durante l'Eocene superiore (Prealpi Venete, provincie di Vicenza e Treviso). Stud Trentini di Scienze Naturali, Acta Geologica 71 (1994), 145-168.

Tripati, A., Backman, J., Elderfield, H., Ferretti, P., 2005. Eocene bipolar glaciation associated with global carbon cycle changes. Nature 436, 341-346.

Ujetz, B., Wernli, R., 1994. Globigerina ciperoensis, atypically giant planktonic foraminifers from the Oligocene of the Haute-Savoie, France. Annalen des Naturhistorischen Museums in Wien 96A, 199-207.

Van Valen, L., 1973. A new evolutionary law. Evolutionary Theory 1 (1), 1-30.

Villa, G., Fioroni, C., Pea, L., Bohaty, S., Persico, D., 2008. Eocene-late Oligocene climate variability: calcareous nannofossil response at Kerguelen Plateau, Site 748. Marine Microplaeontology 69, 173-192.

Violanti, D., Premoli Silva, I. Cita, M.B. Kersey, D. Hsu, KJ. 1979. Quantitative characterization of carbonate dissolution facies of the Atlantic Tertiary sediments. An attempt. Rivista Italiana di Paleontologia e Stratigrafia 85 (2), 517-548.

Wade, B.S., 2004. Planktonic foraminiferal biostratigraphy and mechanisms in the extinction of Morozovella in the late Middle Eocene. Marine Micropaleontology 51 23-38.

Winterer, E.L., Bosellini, A., 1981. Subsidence and sedimentation on Jurassic passive continental margin, Southern Alps, Italy. American Association of Petroleum Geologists Bulletin 65, 394-421.

Yanko, V., Ahmad, M., Kaminski, M.A., 1998. Morphological deformities of benthic foraminiferal tests to response to pollution by heavy metals: implications for pollution monitoring. Journal of Foraminiferal Research 28, 177-200.

Zachos, J.C., Pagani, M., Sloan, L.C., Thomas, E., Billups, K., 2001. Trends, rhythms, and aberrations in global climate 65 Ma to present. Science 292, 686-693.

Zachos, J.C., Dickens, G.R., Zeebe, R.E., 2008. An early Cenozoic perspective on greenhouse warming and carbon-cycle dynamics. Nature 451,279-283. doi:10.1038/nature06588. 